In cooperation with the Capital Area Ground Water Conservation Commission

\title{
Chloride Concentrations in Ground Water in East and West Baton Rouge Parishes, Louisiana, 2004-05
}

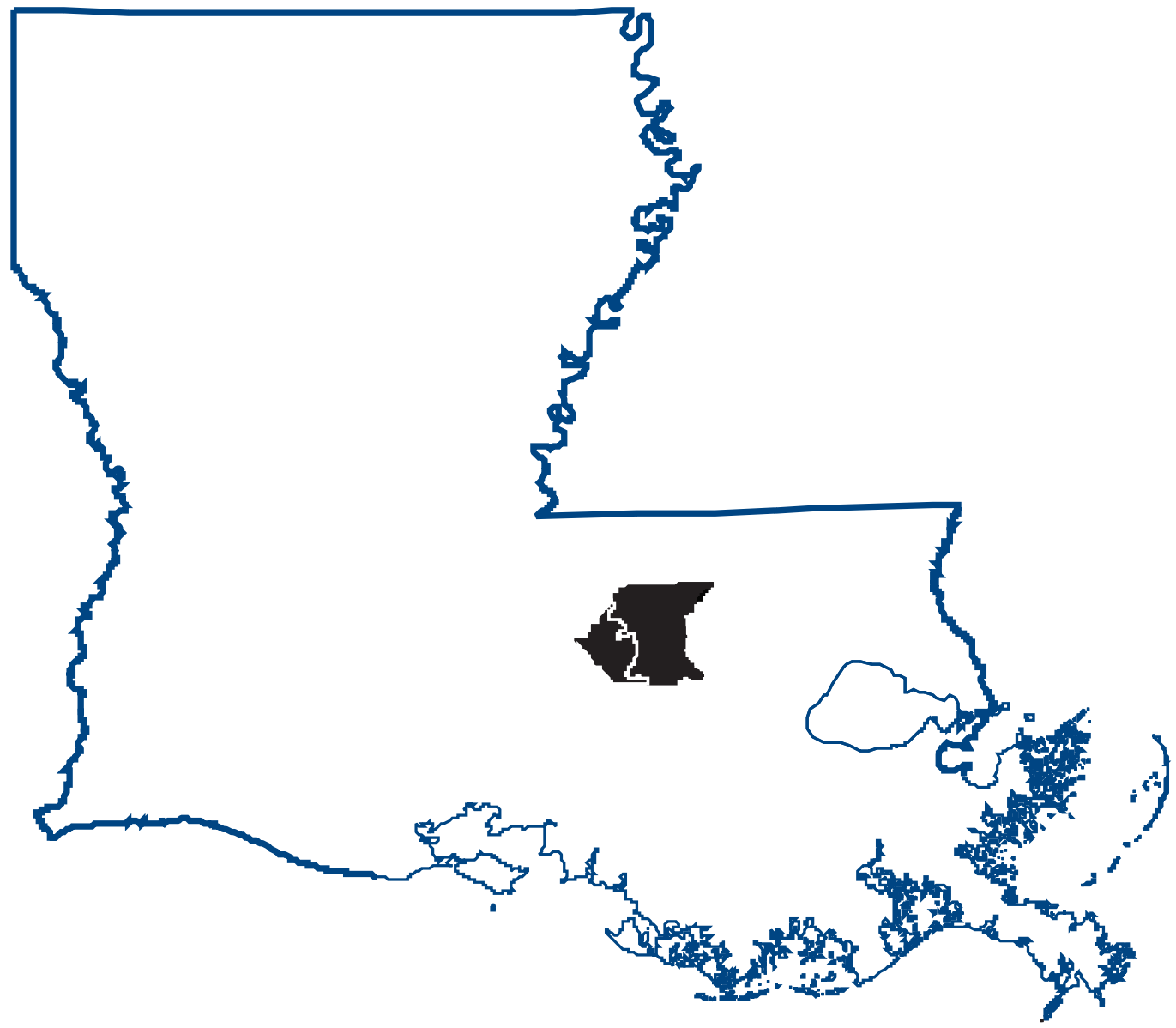

Scientific Investigations Report 2007-5069 
Blank Page 


\section{Chloride Concentrations in Ground Water in East and West Baton Rouge Parishes, Louisiana, 2004-05}

By John K. Lovelace

In cooperation with the Capital Area Ground Water Conservation Commission

Scientific Investigations Report 2007-5069 


\title{
U.S. Department of the Interior DIRK KEMPTHORNE, Secretary
}

\author{
U.S. Geological Survey \\ Mark D. Myers, Director
}

\section{U.S. Geological Survey, Reston, Virginia: 2007}

For product and ordering information:

World Wide Web: http://www.usgs.gov/pubprod

Telephone: 1-888-ASK-USGS

For more information on the USGS — the Federal source for science about the Earth, its natural and living resources, natural hazards, and the environment:

World Wide Web: http://www.usgs.gov

Telephone: 1-888-ASK-USGS

Any use of trade, product, or firm names is for descriptive purposes only and does not imply endorsement by the U.S. Government.

Although this report is in the public domain, permission must be secured from the individual copyright owners to reproduce any copyrighted materials contained within this report.

Suggested citation:

Lovelace, J.K., 2007, Chloride concentrations in ground water in East and West Baton Rouge Parishes, Louisiana, 2004-05: U.S. Geological Survey Scientific Investigations Report 2007-5069, 27 p. 


\section{Contents}

Abstract
Introduction
Purpose and Scope
Description of Study Area
Methods
Acknowledgments
Chdrogeology

\section{Figures}

1. Map showing location of study area and chloride concentrations in water from wells screened in the " 400 -foot" sand of the Baton Rouge area in East and West Baton Rouge Parishes, Louisiana, 2004-05

2. Graph showing withdrawals from aquifers in East and West Baton Rouge Parishes, Louisiana, 2005

3. Diagram showing hydrogeologic units in the Baton Rouge area, southeastern Louisiana

4. Map showing chloride concentrations in water from wells screened in the "600-foot" sand of the Baton Rouge area in East and West Baton Rouge Parishes, Louisiana, 2004-05

5. Graph showing chloride concentrations in water from well EB-793 screened in the "600-foot" sand of the Baton Rouge area, Louisiana

6. Map showing chloride concentrations in water from wells screened in the "800-foot" sand of the Baton Rouge area in East and West Baton Rouge Parishes, Louisiana, 2004-05

7. Map showing chloride concentrations in water from wells screened in the "1,000-foot" sand of the Baton Rouge area in East and West Baton Rouge Parishes, Louisiana, 2004-05

8. Graph showing chloride concentrations in water from well EB-805 screened in the "1,000-foot" sand of the Baton Rouge area, Louisiana 
9. Map showing chloride concentrations in water from wells screened in the "1,200-foot" sand of the Baton Rouge area in East and West Baton Rouge Parishes, Louisiana, 2004-05

10. Graph showing chloride concentrations in water from well EB-621 screened in the "1,200-foot" sand of the Baton Rouge area, Louisiana

11. Map showing chloride concentrations in water from wells screened in the "1,500-foot" sand of the Baton Rouge area in East and West Baton Rouge Parishes, Louisiana, 2004-05

12-16. Graphs showing:

12. Chloride concentrations in water from wells EB-917 and EB-918 screened in the "1,500-foot" sand of the Baton Rouge area, Louisiana

13. Chloride concentrations in water from wells EB-413 and EB-771 screened in the "1,500-foot" sand of the Baton Rouge area, Louisiana

14. Chloride concentrations in water from wells EB-510 and EB-658 screened in the "1,500-foot" sand of the Baton Rouge area, Louisiana

15. Chloride concentrations in water from wells WBR-112 and WBR-113 screened in the "1,500-foot" sand of the Baton Rouge area, Louisiana

16. Chloride concentrations in water from wells WBR-132 and WBR-173 screened in the "1,500-foot" sand of the Baton Rouge area, Louisiana

17. Map showing chloride concentrations in water from wells screened in the "1,700-foot" sand of the Baton Rouge area in East and West Baton Rouge Parishes, Louisiana, 2004-05

18. Map showing chloride concentrations in water from wells screened in the "2,000-foot" sand of the Baton Rouge area in East and West Baton Rouge Parishes, Louisiana, 2004-05

19. Graph showing chloride concentrations in water from wells EB-630, EB-1028, and EB-1150 screened in the "2,000-foot" sand of the Baton Rouge area, Louisiana

20. Map showing chloride concentrations in water from wells screened in the "2,400-foot" sand of the Baton Rouge area in East and West Baton Rouge Parishes, Louisiana, 2004-05

21. Graph showing chloride concentrations in water from well EB-804B screened in the "2,400-foot" sand of the Baton Rouge area, Louisiana

22. Map showing chloride concentrations in water from wells screened in the "2,800-foot" sand of the Baton Rouge area in East and West Baton Rouge Parishes, Louisiana, 2004-05 25

23. Graph showing chloride concentrations in water from wells EB-750 and EB-798 screened in the "2,800-foot" sand of the Baton Rouge area, Louisiana .25

\section{Tables}

1. Comparison of chloride concentrations in samples and sequential replicates collected for quality assurance purposes

2. Selected data, including specific conductance values and chloride concentrations, for wells in East and West Baton Rouge Parishes, Louisiana, 2004-05 


\section{Conversion Factors, Datums, and Abbreviated Water-Quality Units}

\begin{tabular}{lcl}
\hline \multicolumn{1}{c}{ Multiply } & By & \multicolumn{1}{c}{ To obtain } \\
\hline inch (in.) & Length & \\
foot (ft) & 25.4 & millimeter $(\mathrm{mm})$ \\
mile (mi) & 0.3048 & meter $(\mathrm{m})$ \\
& 1.609 & kilometer $(\mathrm{km})$ \\
\hline square mile $\left(\mathrm{mi}^{2}\right)$ & Area & \\
\hline & 2.590 & square kilometer $\left(\mathrm{km}^{2}\right)$ \\
\hline million gallons per day $(\mathrm{Mgal} / \mathrm{d})$ & Flow rate & \\
\hline
\end{tabular}

Temperature in degrees Celsius $\left({ }^{\circ} \mathrm{C}\right)$ can be converted to degrees Fahrenheit $\left({ }^{\circ} \mathrm{F}\right)$ as follows: ${ }^{\circ} \mathrm{F}=\left(1.8 \mathrm{x}^{\circ} \mathrm{C}\right)+32$

\section{Datums}

Vertical coordinate information in this report is referenced to the National Geodetic Vertical Datum of 1929 (NGVD 29).

Horizontal coordinate information in this report is referenced to the North American Datum of 1927 (NAD 27).

\section{Abbreviated Water-Quality Units}

Specific conductance is given in microsiemens per centimeter at 25 degrees Celsius $(\mu \mathrm{S} / \mathrm{cm}$ at $\left.25^{\circ} \mathrm{C}\right)$.

Concentrations of chloride in water are given in milligrams per liter $(\mathrm{mg} / \mathrm{L})$. 
Blank Page 


\title{
Chloride Concentrations in Ground Water in East and West Baton Rouge Parishes, Louisiana, 2004-05
}

\author{
By John K. Lovelace
}

\section{Abstract}

Increasing chloride concentrations are a threat to fresh ground-water sources in East Baton Rouge and West Baton Rouge Parishes, Louisiana. Large withdrawals at Baton Rouge have lowered water levels and altered flow patterns in most of the 10 aquifers that underlie the area. Prior to development, freshwater flowed southward to the Baton Rouge fault, an east-west trending growth fault that extends through Baton Rouge and across southeastern Louisiana. Aquifers south of the fault generally contain saltwater. Ground-water withdrawals north of the fault have created gradients favorable for the movement of saltwater from south of the fault into freshwater areas north of the fault.

Water samples were collected from 152 wells during 2004-05 to document chloride concentrations in aquifers underlying East and West Baton Rouge Parishes. The background concentration for chloride in fresh ground water in the Baton Rouge area north of the Baton Rouge fault is generally less than 10 milligrams per liter. Chloride concentrations exceeded 10 milligrams per liter in one or more samples from wells north of the fault screened in the "600foot," "1,000-foot," "1,200-foot," "1,500-foot," "1,700-foot," "2,000-foot," "2,400-foot," and "2,800-foot" sands. Comparison of the 2004-05 data with historical data indicated that chloride concentrations are increasing at wells in the "600foot," "1,000-foot," "1,200-foot," "1,500-foot," "2,000-foot," "2,400-foot," and "2,800-foot" sands north of the Baton Rouge fault.

\section{Introduction}

Increasing chloride concentrations are a threat to fresh ground-water sources in East and West Baton Rouge Parishes, Louisiana (fig. 1). In 2005, approximately $153 \mathrm{Mgal} / \mathrm{d}$ of water was withdrawn from 10 aquifers in East and West Baton Rouge Parishes (fig. 2) (B.P. Sargent, U.S. Geological Survey, written commun., 2007). The aquifers include the "400-foot," "600-foot," "800-foot," "1,000-foot," "1,200-foot," "1,500-foot," "1,700-foot," "2,000-foot," “2,400-foot," and "2,800-foot" sands of the Baton Rouge area. About 70 percent of the water was withdrawn in or near the City of Baton Rouge for public supply or industrial uses (B.P. Sargent, U.S.
Geological Survey, written commun., 2007). Large withdrawals at Baton Rouge have lowered water levels and altered flow patterns in most of the 10 aquifers that underlie the area (Tomaszewski, 1996). Prior to development, freshwater flowed southward to the Baton Rouge fault, an east-west trending growth fault that extends through Baton Rouge and across southeastern Louisiana. Aquifers south of the fault generally contain saltwater. ${ }^{1}$ Ground-water withdrawals north of the fault have created gradients favorable for the movement of saltwater from south of the fault into freshwater areas north of the fault (Tomaszewski, 1996, p. 1).

Saltwater encroachment, which is the migration of saltwater into a freshwater area, was first documented in an aquifer beneath the Baton Rouge area, the "600-foot" sand, by Meyer and Turcan (1955). Since that time, saltwater encroachment also has been documented in the "800-foot," "1,000foot," "1,500-foot," and "2,000-foot" sands underlying East and West Baton Rouge Parishes (Morgan and Winner, 1964; Whiteman, 1979; Tomaszewski, 1996). These studies also documented the presence, but not encroachment, of saltwater in the "400-foot," "1,200-foot," and "2,800-foot" sands north of the Baton Rouge fault.

Using data collected through 1992, Tomaszewski (1996) showed that saltwater encroachment had continued in the "1,500-foot" and "2,000-foot" sands. Data collected from 1993 to 2003 from wells in a chloride-monitoring network indicate concentrations of chloride have increased in wells in the "1,000-foot," "1,500-foot," "2,000-foot," "2,400-foot," and "2,800-foot" sands in East and West Baton Rouge Parishes. Data from additional wells are needed to document current (2004-05) chloride concentrations in aquifers underlying the Baton Rouge area. In response to this need, the U.S. Geological Survey (USGS), in cooperation with the Capital Area Ground Water Conservation Commission, began a study in 2004 to document chloride concentrations in selected wells in East and West Baton Rouge Parishes.

${ }^{1}$ For the purposes of this report, saltwater is defined as water containing greater than $250 \mathrm{mg} / \mathrm{L}$ chloride. Concentrations of chloride greater than $250 \mathrm{mg} / \mathrm{L}$ exceed the Secondary Maximum Contaminant Level (SMCL) for drinking water (U.S. Environmental Protection Agency, 2006). SMCLs are established for contaminants that can adversely affect the aesthetic quality of drinking water. At high concentrations or values, health implications as well as aesthetic degradation also may exist. SMCLs are not federally enforceable, but are intended as guidelines for the states. 


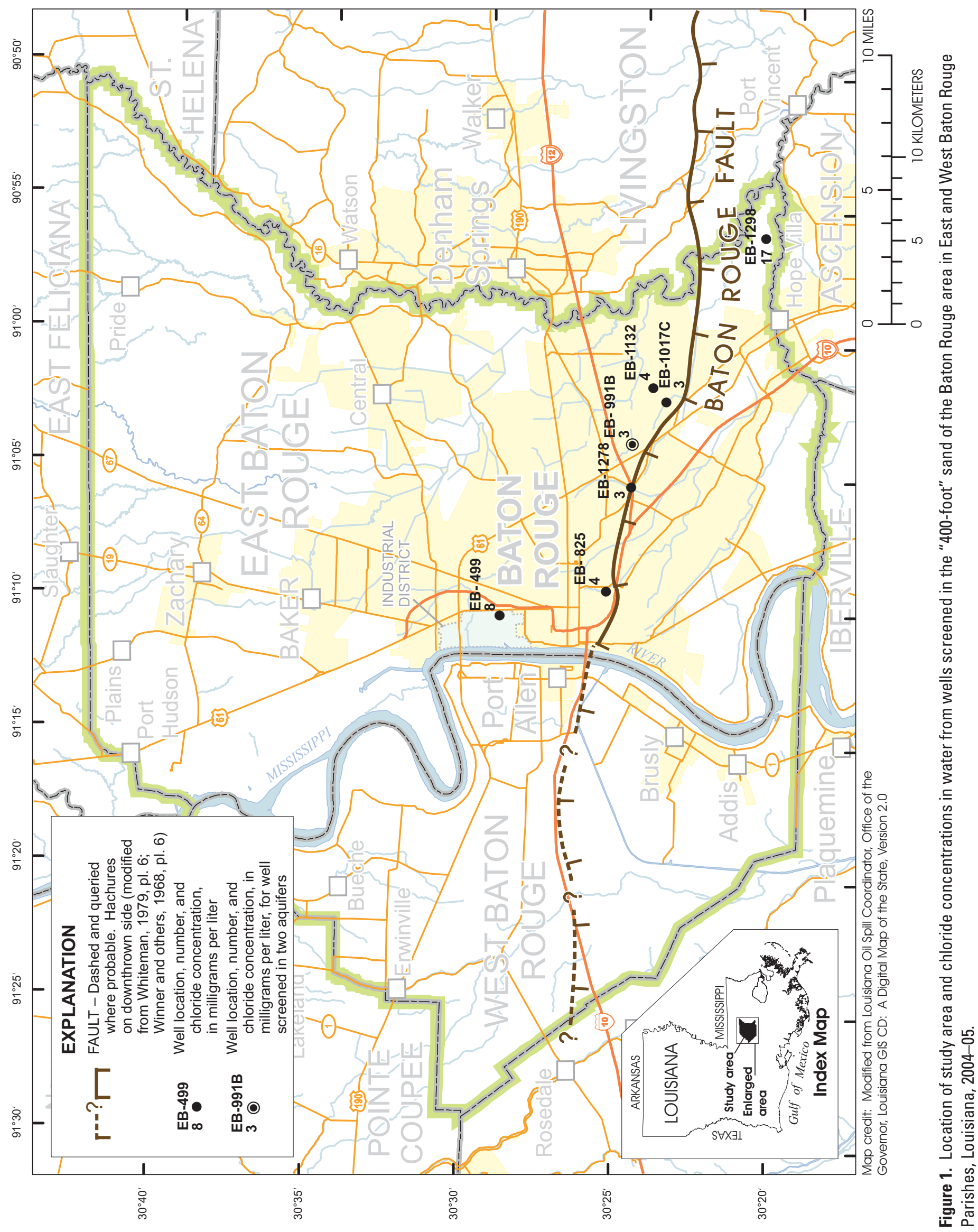




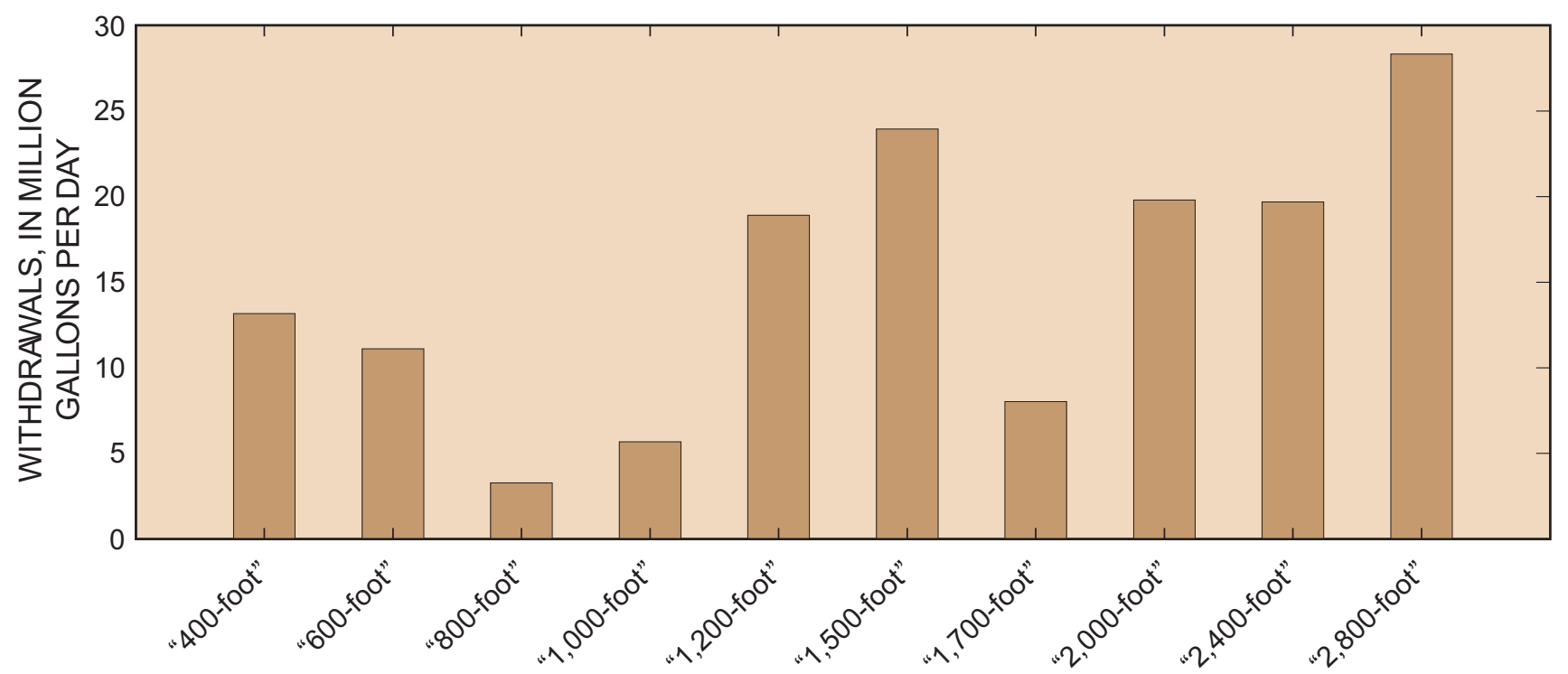

Sand of the Baton Rouge area

Figure 2. Withdrawals from aquifers in East and West Baton Rouge Parishes, Louisiana, 2005 (B.P. Sargent, U.S. Geological Survey, written commun., 2007).

\section{Purpose and Scope}

This report describes current (2004-05) chloride concentrations in ground water in East and West Baton Rouge Parishes. Data were collected from 152 wells, and selected data were collected and analyzed for quality-assurance and quality-control purposes. The data include wells sampled for routine chloride-monitoring purposes during the study period. This report documents and compares differences between historical and 2004-05 data. Well-construction information, specific conductance, and chloride concentrations for wells sampled during 2004-05 are presented by aquifer in a table. In addition, chloride concentrations in water from wells screened in the aquifers are presented on maps. Long-term changes in chloride concentrations at selected wells are presented in graphs. All data presented are stored in the USGS National Water Information System data base and are available at the USGS office in Baton Rouge, La. Information in this report may be useful to State and local water managers and planners and may help improve understanding of water-quality conditions in similar hydrogeologic settings in other areas of the United States.

\section{Description of Study Area}

The study area in southeasern Louisiana extends across about $645 \mathrm{mi}^{2}$ and includes East and West Baton Rouge Parishes, which are separated by the Mississippi River (fig. 1). East Baton Rouge Parish had an estimated population of 412,000 in 2004 (U.S. Census Bureau, 2005), and large areas of the parish are residential and commercial. West Baton Rouge Parish had an estimated population of 21,880 in 2004 (U.S. Census Bureau, 2005), and much of the Parish is rural with large areas of forested wetlands. Baton Rouge, the largest city in the study area, and several industrial facilities are located along the Mississippi River (fig. 1). The climate in the study area is generally warm and temperate with high humidity and frequent rain. At Baton Rouge, the average annual temperature is $68^{\circ} \mathrm{F}$, and the average annual rainfall is about 60 in. (National Oceanic and Atmospheric Administration, 1995, p. 5 and 8).

\section{Methods}

Wells generally were selected to sample based on their proximity to the Baton Rouge fault or areas of saltwater delineated by Tomaszewski (1996). Many wells were sampled multiple times to determine whether chloride concentrations were changing during the study at the wells. Chloride data collected during this study were compared to historical data to determine whether chloride concentrations were changing over longer periods of time at the wells.

Water samples were collected from wells at a spigot or other discharge outlet; specific conductance and water temperature were measured in the field using methods described in U.S. Geological Survey (1997-present). Samples were sent to the USGS National Water Quality Laboratory in Denver, Colo. for analysis of specific conductance and dissolved chloride concentration using laboratory methods described in Fishman and Friedman (1989). For quality-assurance and quality-control purposes, sequential replicates were collected from 18 wells. Several of the replicates were analyzed for major inorganic ions in addition to specific conductance, temperature, and chloride concentrations. Quality-assurance data for chloride analyses are presented in table 1. Other data are on file at the USGS office in Baton Rouge. 
Table 1. Comparison of chloride concentrations in samples and sequential replicates collected for quality assurance purposes.

\begin{tabular}{|c|c|c|c|c|c|}
\hline \multirow[b]{2}{*}{ Well number } & \multirow[b]{2}{*}{ Date sampled } & \multicolumn{3}{|c|}{ Chloride concentration, in milligrams per liter } & \multirow[b]{2}{*}{$\begin{array}{c}\text { Percent difference }{ }^{1} \\
\text { between chloride } \\
\text { concentrations in sample } \\
\text { and sequential replicate }\end{array}$} \\
\hline & & Sample & $\begin{array}{l}\text { Sequential } \\
\text { replicate }\end{array}$ & $\begin{array}{l}\text { Absolute value of the } \\
\text { difference between } \\
\text { sample and sequential } \\
\text { replicate }\end{array}$ & \\
\hline EB- 151 & $11-17-05$ & 2.41 & 2.56 & 0.15 & 6.00 \\
\hline EB- 772 & $9-02-04$ & 4.18 & 4.17 & 0.01 & 0.31 \\
\hline EB- 813 & 9-03-04 & 2.04 & 2.08 & 0.04 & 2.04 \\
\hline EB- 851 & 9-29-04 & 2.19 & 2.18 & 0.01 & 0.37 \\
\hline EB- 874 & $9-03-04$ & 2.19 & 2.19 & 0.00 & 0.00 \\
\hline EB- 917 & $12-05-05$ & 64.8 & 69.2 & 4.40 & 6.55 \\
\hline EB- 978 & 9-30-04 & 11.5 & 11.5 & 0.00 & 0.21 \\
\hline EB- 995 & $9-17-04$ & 4.72 & 4.65 & 0.07 & 1.52 \\
\hline EB-1004 & 4-13-05 & 2.3 & 2.26 & 0.04 & 1.58 \\
\hline EB-1016B & 4-13-05 & 2.52 & 2.57 & 0.05 & 1.85 \\
\hline EB-1123 & 4-13-05 & 5.36 & 4.77 & 0.59 & 11.61 \\
\hline EB-1150 & $9-02-04$ & 167 & 167 & 0.00 & 0.22 \\
\hline EB-1187 & $9-24-04$ & 2.98 & 2.99 & 0.01 & 0.37 \\
\hline EB-1278 & $11-10-05$ & 2.66 & 2.47 & 0.19 & 7.53 \\
\hline EB-1303 & $9-02-04$ & 4.58 & 4.53 & 0.05 & 1.05 \\
\hline WBR- 110 & $12-23-04$ & 3.27 & 3.42 & 0.15 & 4.51 \\
\hline WBR- 113 & $12-19-05$ & 221 & 221 & 0.00 & 0.07 \\
\hline WBR- 152 & $7-14-05$ & 5.07 & 5.09 & 0.02 & 0.35 \\
\hline
\end{tabular}

${ }^{1}$ Percent difference was calculated by multiplying 100 by the absolute value of the difference between the sample and sequential replicate chloride concentrations divided by the average of the sample and sequential replicate chloride concentrations.

In the Baton Rouge area, wells often have multiple screened intervals. In some instances, wells are screened in more than one aquifer. In this report, wells screened in more than one aquifer are included in the discussions and on maps for both aquifers in which the wells are screened, but are listed under separate subheadings that include both aquifer names in the tables.

\section{Acknowledgments}

The author gratefully acknowledges the assistance of public-water suppliers, industries, and private well owners who allowed samples to be collected from their wells. A special thanks is given to the Baton Rouge Water Company and Parish Water Company for providing access and knowledgeable escorts to their numerous wells. Thanks to U.S. Geological Survey employees, Michael L. Ross and Robert B. Fendick, Jr., who assisted with sample collection. Thanks also to Zahir "Bo" Bolourchi, Chief, Public Works and Water Resources Section, Louisiana Department of Transportation and Development, for providing well information that was used during this study.

\section{Hydrogeology}

Ten freshwater-bearing aquifers beneath the study area were named for their general depth below land surface in the Baton Rouge industrial district (fig. 3) (Meyer and Turcan, 1955, p. 13). These aquifers primarily consist of beds of unconsolidated sand that generally thicken and dip to the south. Although the aquifers vary in thickness and pinch out locally, the aquifers generally are at least $75 \mathrm{ft}$ thick and can be more than $200 \mathrm{ft}$ thick. The confining units between the aquifers consist of clay and silt, and generally are at least $100 \mathrm{ft}$ thick, but may be $500 \mathrm{ft}$ thick in some areas (Tomaszewski, 1996).

Precipitation north of the study area in Louisiana and Mississippi is the primary source of recharge to the aquifers (Morgan, 1963, p. 11-13). Generally, water moves downdip 


\begin{tabular}{|c|c|c|c|c|c|}
\hline System & Series & & Stratigraphic unit & \multicolumn{2}{|c|}{ Aquifer ${ }^{1}$ or confining unit } \\
\hline \multirow{4}{*}{ 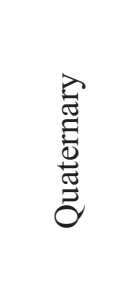 } & \multirow{4}{*}{$\begin{array}{l}\text { Holocene } \\
? \\
\text { Pleistocene }\end{array}$} & \multicolumn{2}{|c|}{$\begin{array}{l}\text { Mississippi River and other } \\
\text { alluvial deposits }\end{array}$} & \multicolumn{2}{|c|}{$\begin{array}{l}\text { Mississippi River } \\
\text { alluvial aquifer }\end{array}$} \\
\hline & & \multirow{3}{*}{\multicolumn{2}{|c|}{ Unnamed Pleistocene deposits }} & \multicolumn{2}{|c|}{ Shallow sands } \\
\hline & & & & \multirow{2}{*}{$\begin{array}{l}\text { Upland terrace } \\
\text { aquifer }\end{array}$} & "400-foot" sand \\
\hline & & & & & "600-foot" sand \\
\hline \multirow{11}{*}{ 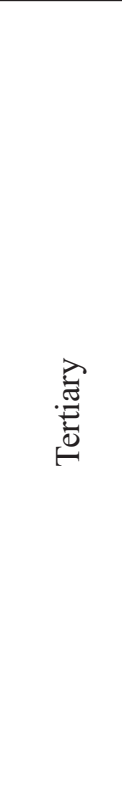 } & \multirow{3}{*}{ Pliocene } & \multirow{10}{*}{ 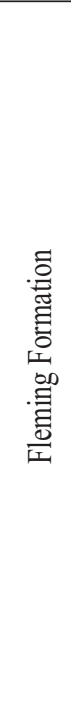 } & & \multicolumn{2}{|c|}{ "800-foot" sand } \\
\hline & & & & \multicolumn{2}{|c|}{ "1,000-foot" sand } \\
\hline & & & $\begin{array}{l}\text { Blounts Creek } \\
\text { Member }\end{array}$ & \multicolumn{2}{|c|}{ "1,200-foot" sand } \\
\hline & \multirow{7}{*}{ Miocene } & & & \multicolumn{2}{|c|}{ "1,500-foot" sand } \\
\hline & & & & \multicolumn{2}{|c|}{ “1,700-foot” sand } \\
\hline & & & Castor Creek Member & \multicolumn{2}{|c|}{ Unnamed confining unit } \\
\hline & & & Williamson Creek & \multicolumn{2}{|c|}{ "2,000-foot" sand } \\
\hline & & & Dough Hills Member & \multicolumn{2}{|c|}{ “2,400-foot” sand } \\
\hline & & & $\begin{array}{l}\text { Carnahan Bayou } \\
\text { Member }\end{array}$ & \multicolumn{2}{|c|}{ "2,800-foot" sand } \\
\hline & & & Lena Member & \multicolumn{2}{|c|}{ Unnamed confining unit } \\
\hline & $\begin{array}{l}\text { Oligocene } \\
\text { O }\end{array}$ & \multicolumn{2}{|c|}{ Catahoula Formation } & \multicolumn{2}{|c|}{ Catahoula aquifer } \\
\hline
\end{tabular}

${ }^{1}$ Clay units separating aquifers in the Baton Rouge area are discontinuous and unnamed.

Figure 3. Hydrogeologic units in the Baton Rouge area, southeastern Louisiana (modified from Stuart and others, 1994, fig. 5; Lovelace and Lovelace, 1995, fig. 1).

in a southerly direction through the aquifers at rates that range from a few tens of feet per year to several hundreds of feet per year (Buono, 1983, p. 24). The southern limit of freshwater in the aquifers generally is considered to be at or near the Baton Rouge fault (Tomaszewski, 1996, p. 6).

The Baton Rouge fault is a leaky hydrologic barrier to ground-water flow. Strata on the south side of the fault are downthrown, with displacement increasing with depth from a few feet or tens of feet near the surface to about $350 \mathrm{ft}$ at the top of the "2,000-foot" sand (Durham and Peeples, 1956; Whiteman, 1979). Prior to development, which began in the late 1800's (Meyer and Turcan, 1955, p. 51), the Baton Rouge fault impeded southward flow of freshwater. However, by 1960 , large cones of depression had developed in several aquifers north of the fault, creating a gradient for northward flow across the fault (Morgan and Winner, 1964). Test drilling and pump tests conducted across the fault in the "600-foot" sand in the early 1970's determined that ground water could move across the fault in response to withdrawals near the fault (Whiteman, 1979).

\section{Chloride Concentrations}

Background concentrations of chloride in fresh ground water in the Baton Rouge area north of the fault generally are less than $10 \mathrm{mg} / \mathrm{L}$. A chloride concentration exceeding $10 \mathrm{mg} / \mathrm{L}$ often indicates the presence of saltwater near a well, especially when the well is located near the Baton Rouge fault. An exception to this is the "2,800-foot" sand that contains naturally occurring saltwater in the southern half of East Baton Rouge Parish and all of West Baton Rouge Parish. Chloride concentrations in the "2,800-foot" sand near a freshwatersaltwater transition zone in the sand often exceed $10 \mathrm{mg} / \mathrm{L}$ but are usually less than $15 \mathrm{mg} / \mathrm{L}$. 


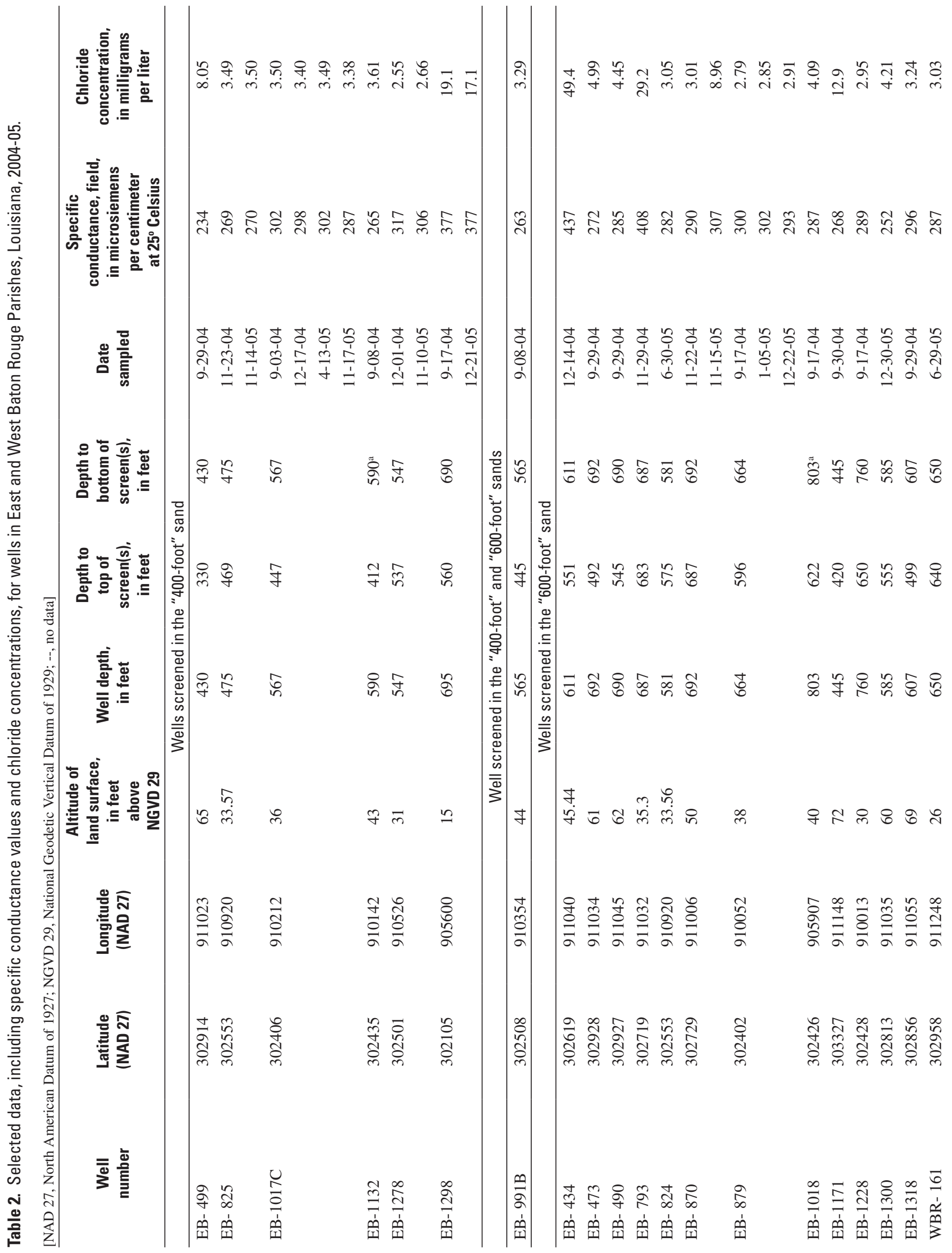




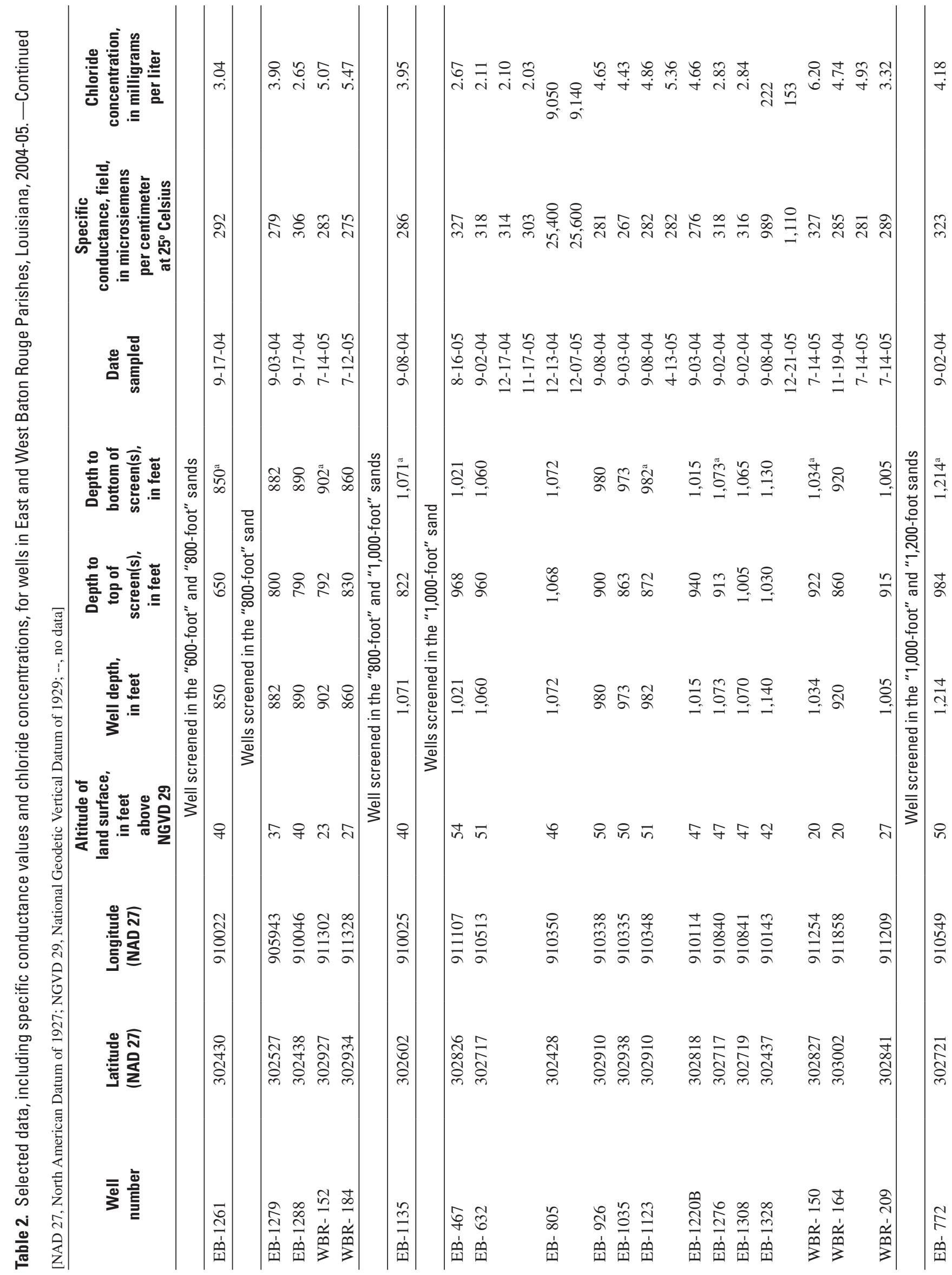




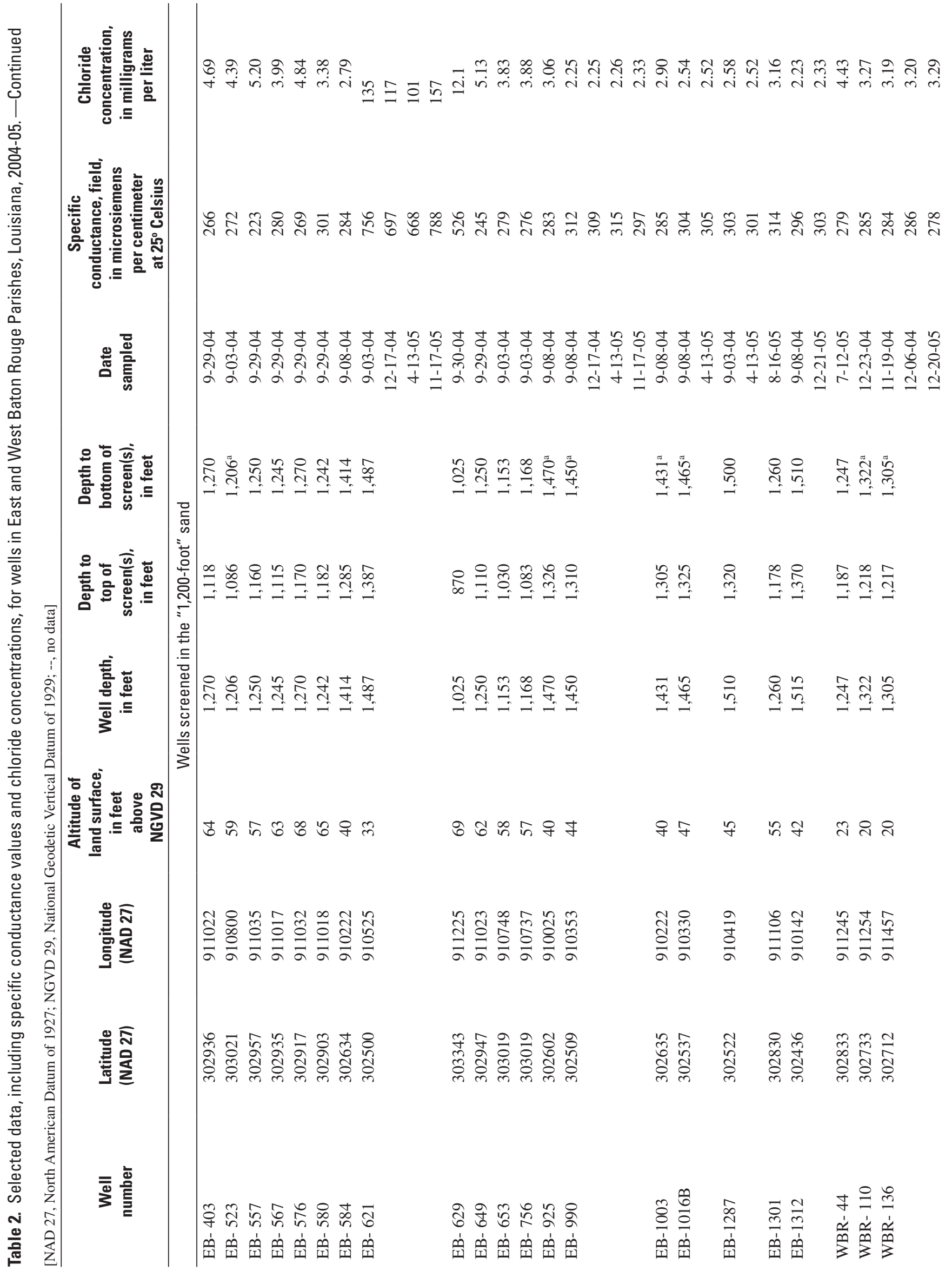




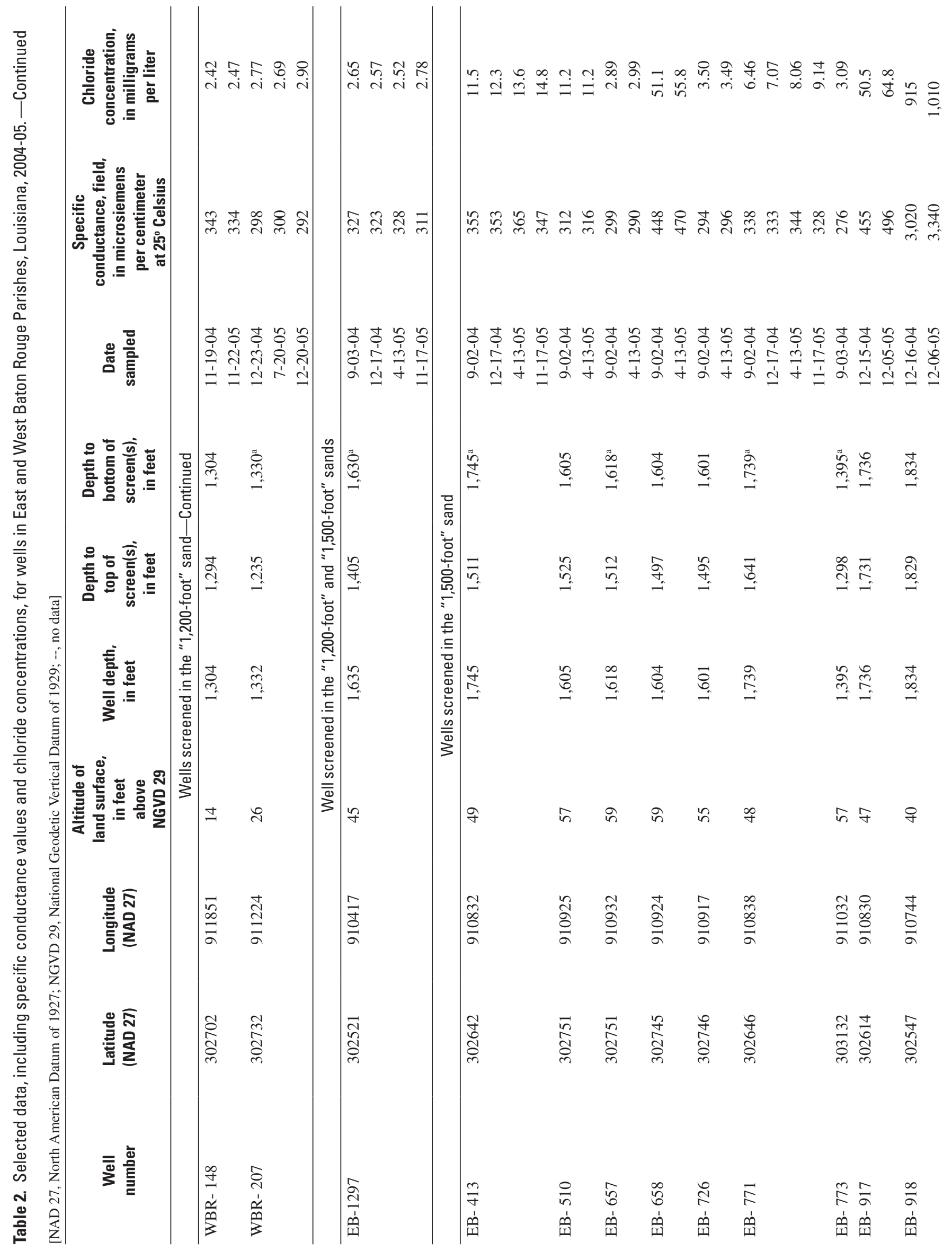




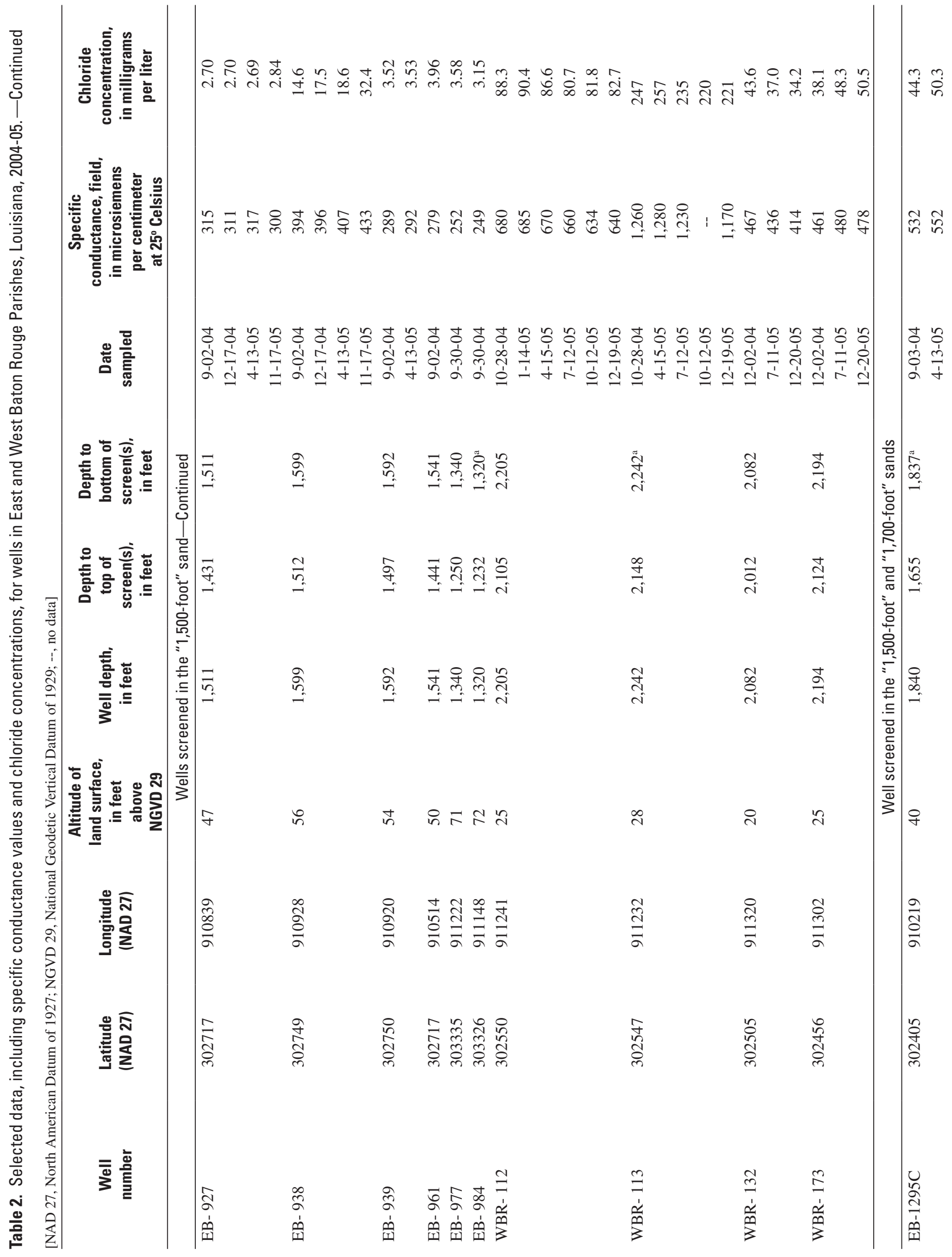




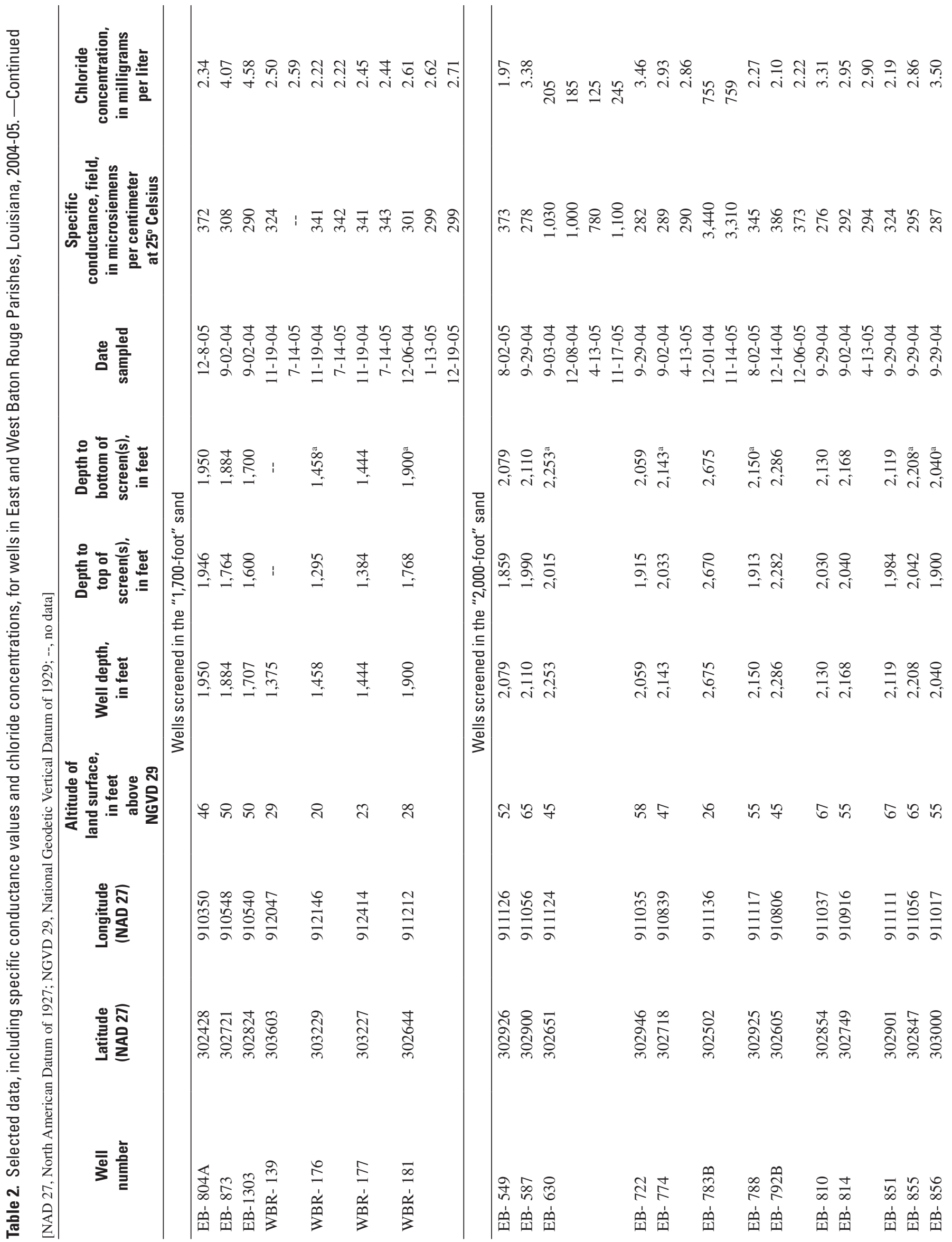




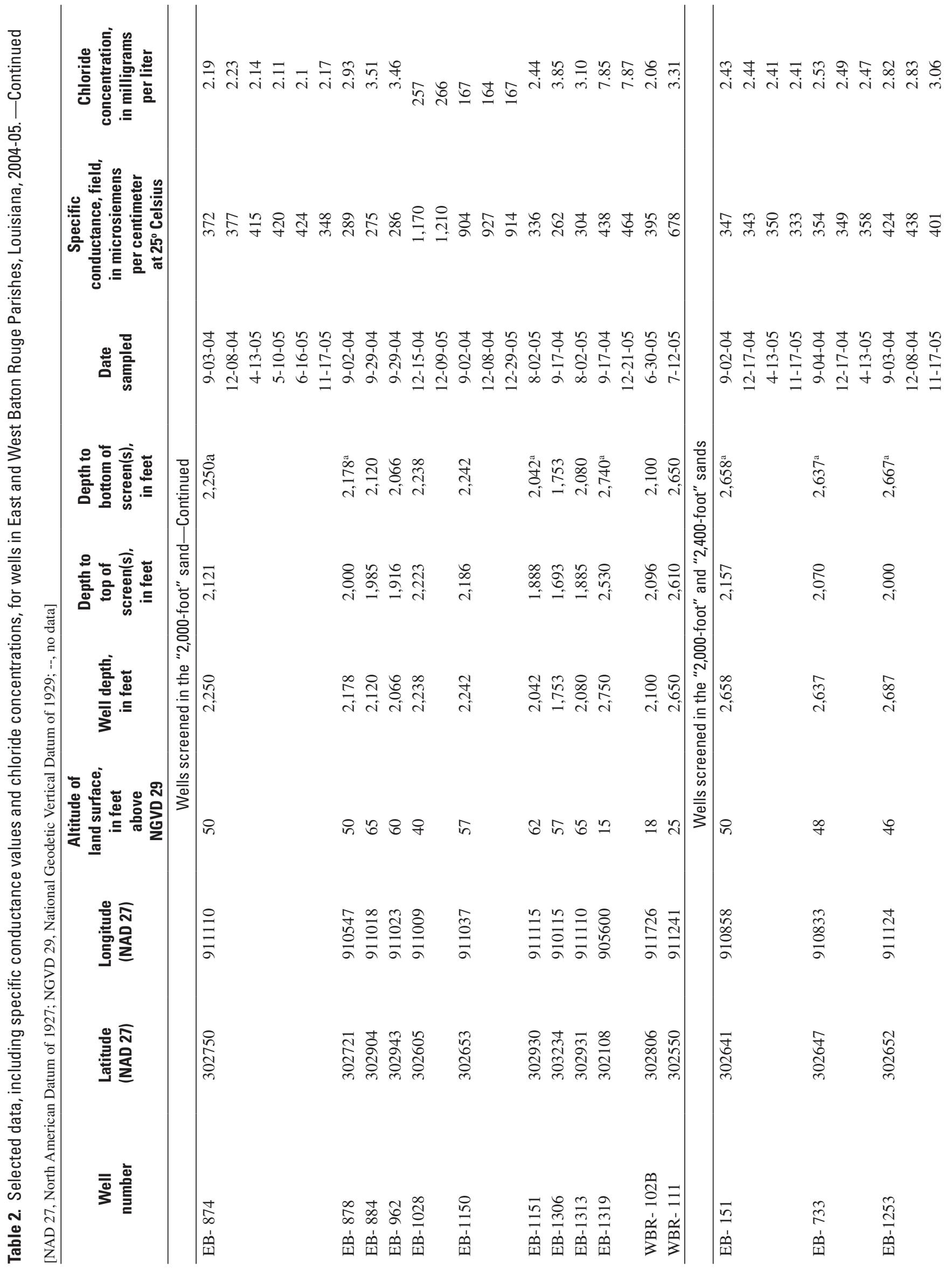




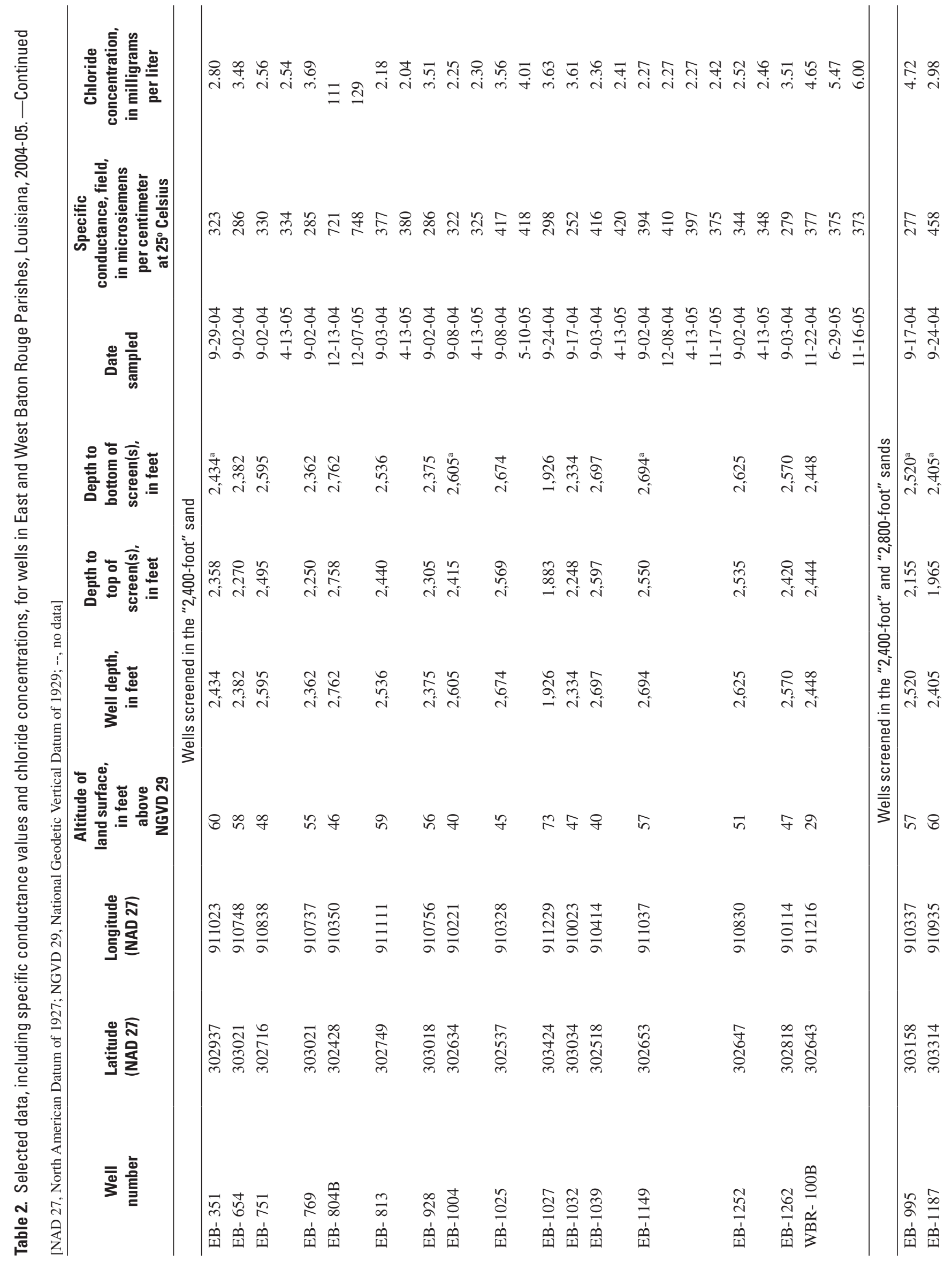




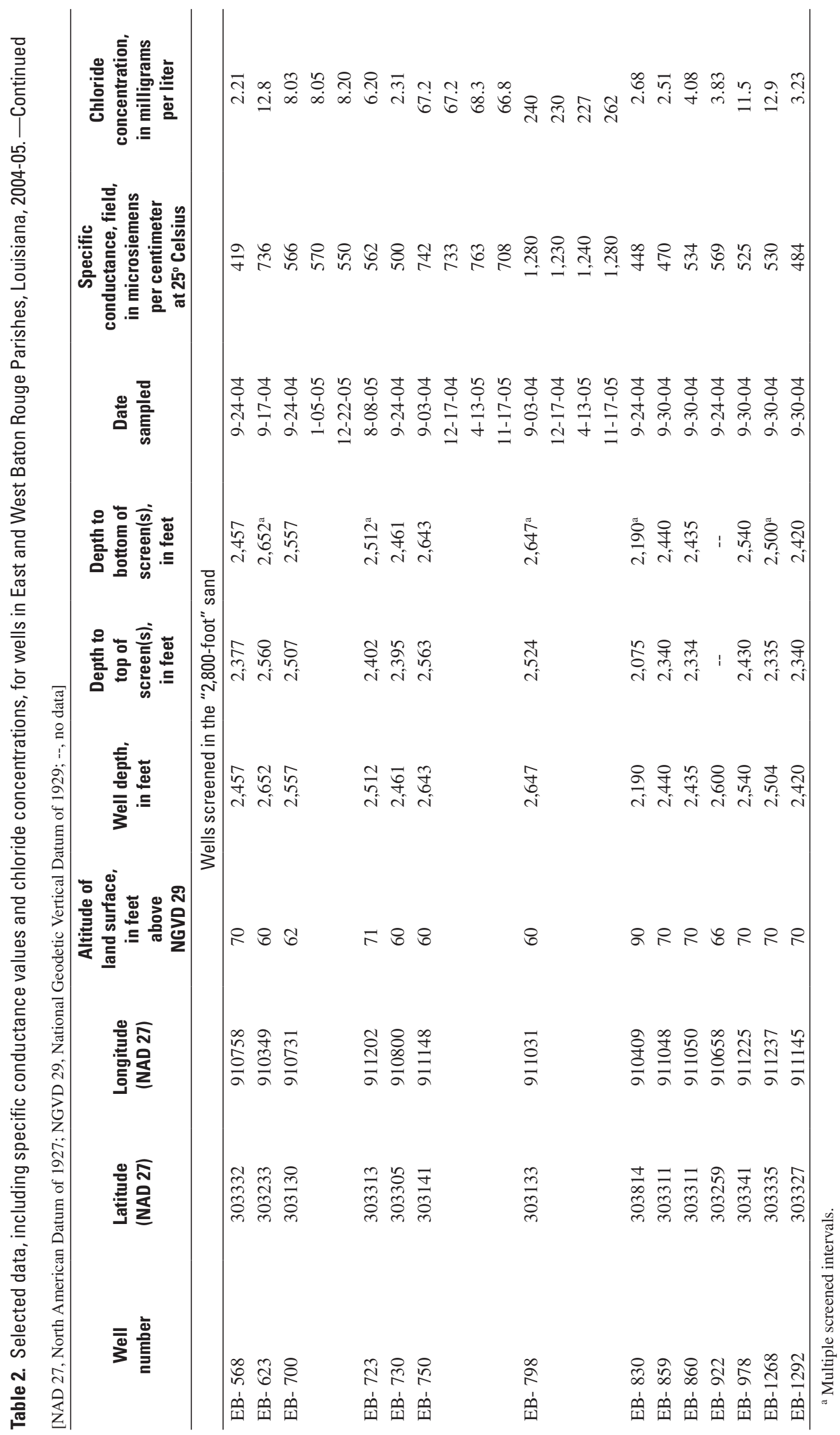




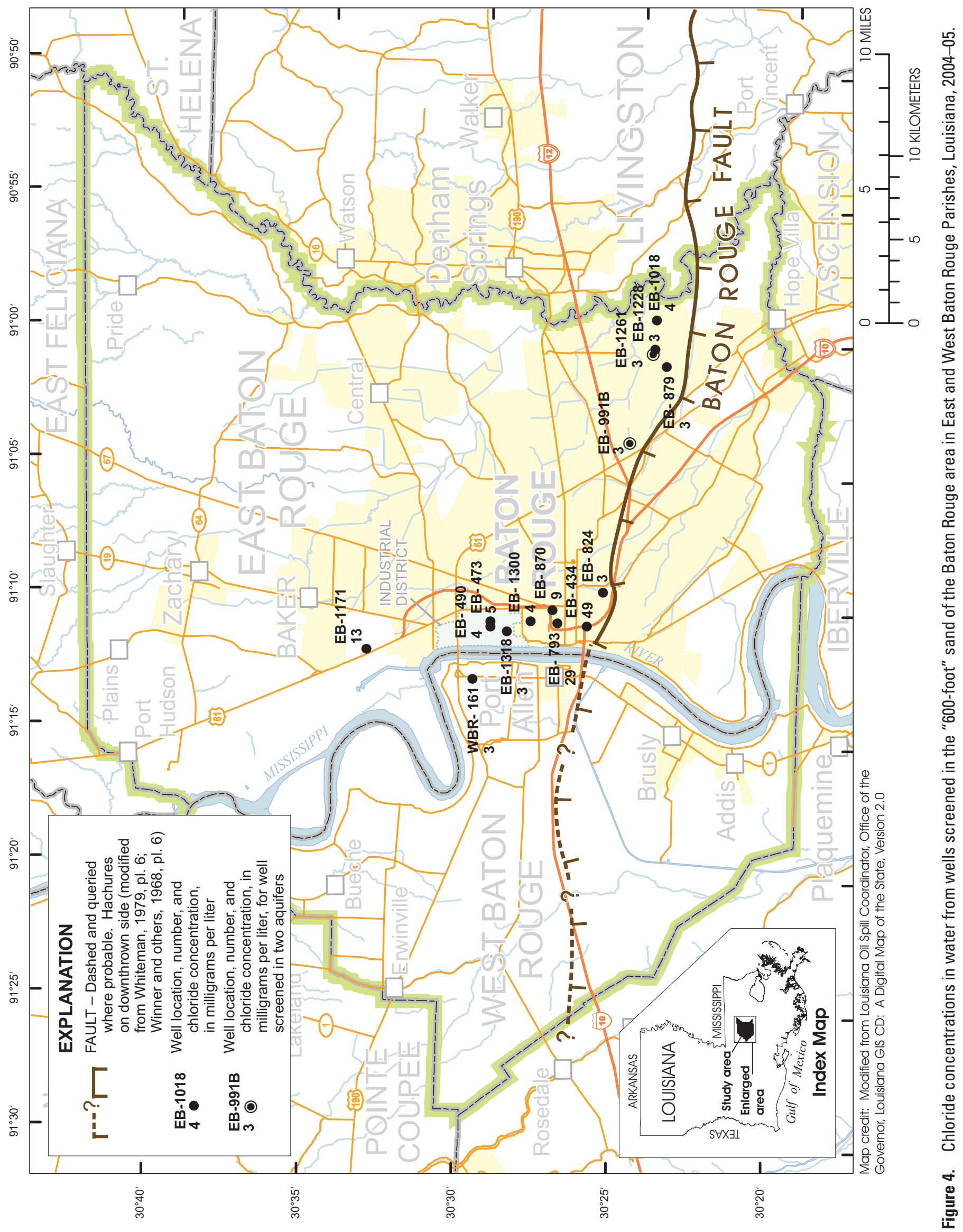


Saltwater movement north of the fault is affected by aquifer permeability, depressions or ridges in the base of the aquifer, and the slope of the base of the aquifer (Tomaszewski, 1996, p. 6). Hydraulic gradients, which are affected by withdrawals in the study area, also affect the direction and rate of saltwater movement. Because saltwater is denser than freshwater, saltwater encroaches into a freshwater aquifer as a wedge, and the leading edge moves along the base of the aquifer as a thin layer. Because largediameter production wells typically have screens that are several tens of feet long, water withdrawn from the well is a mixture of water entering the screen at various depths along the screen. When chloride concentrations at such wells exceed $10 \mathrm{mg} / \mathrm{L}$, it probably is an indication that a thin layer of saltwater with a higher chloride concentration is present at the base of the aquifer, but is being mixed in the well with overlying freshwater that also is entering the screen.

Of the 152 wells sampled during 2004-05, chloride concentrations exceeded $10 \mathrm{mg} / \mathrm{L}$ in samples from 23 wells located north of the Baton Rouge fault, which indicated the possible presence of saltwater in 8 of the 10 aquifers. Comparison of the sample results with historical data indicated that chloride concentrations are increasing at wells north of the Baton Rouge fault in seven of the aquifers. Summaries of findings for each aquifer are presented in the following sections. Selected well data and chloride concentrations from the sampled wells are presented in table 2. For the purposes of this report, the last chloride concentration measured from a well was used on maps when multiple samples had been collected from that well during the study.

\section{“400-Foot" Sand}

Samples were collected from five wells located just north of the Baton Rouge fault, one well in the Baton Rouge industrial district, and one well south of the fault (fig. 1, table 2). Chloride concentrations at wells north of the fault did not exceed background concentrations, and no increase in chloride concentrations was indicated at the wells. The downthrown sands on the south side of the fault, which oppose the "400-foot" sand on the north side of the fault, mostly contain freshwater in East Baton Rouge Parish, and the only real threat of saltwater encroachment into the "400-foot" sand north of the fault is from upward migration of saltwater from the underlying "600-foot" sand (Whiteman, 1979, p. 36). A large-diameter well, EB-1298, located south of the fault in the southeast corner of East Baton Rouge Parish, was sampled and had a chloride concentration of $17.1 \mathrm{mg} / \mathrm{L}$. No increase in chloride concentrations was indicated at well EB-1298.

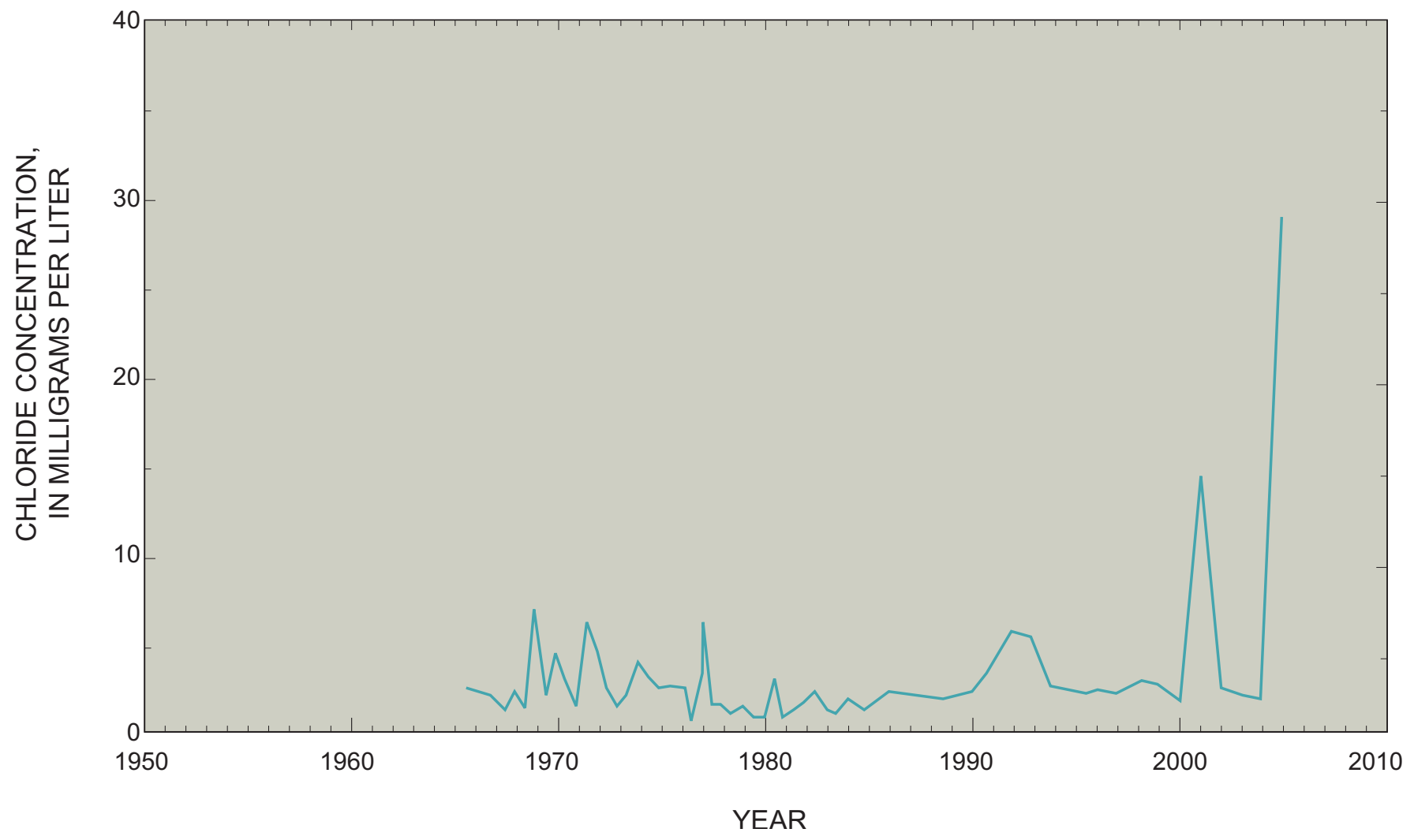

Figure 5. Chloride concentrations in water from well EB-793 screened in the "600-foot" sand of the Baton Rouge area, Louisiana (see fig. 4 for well location). 


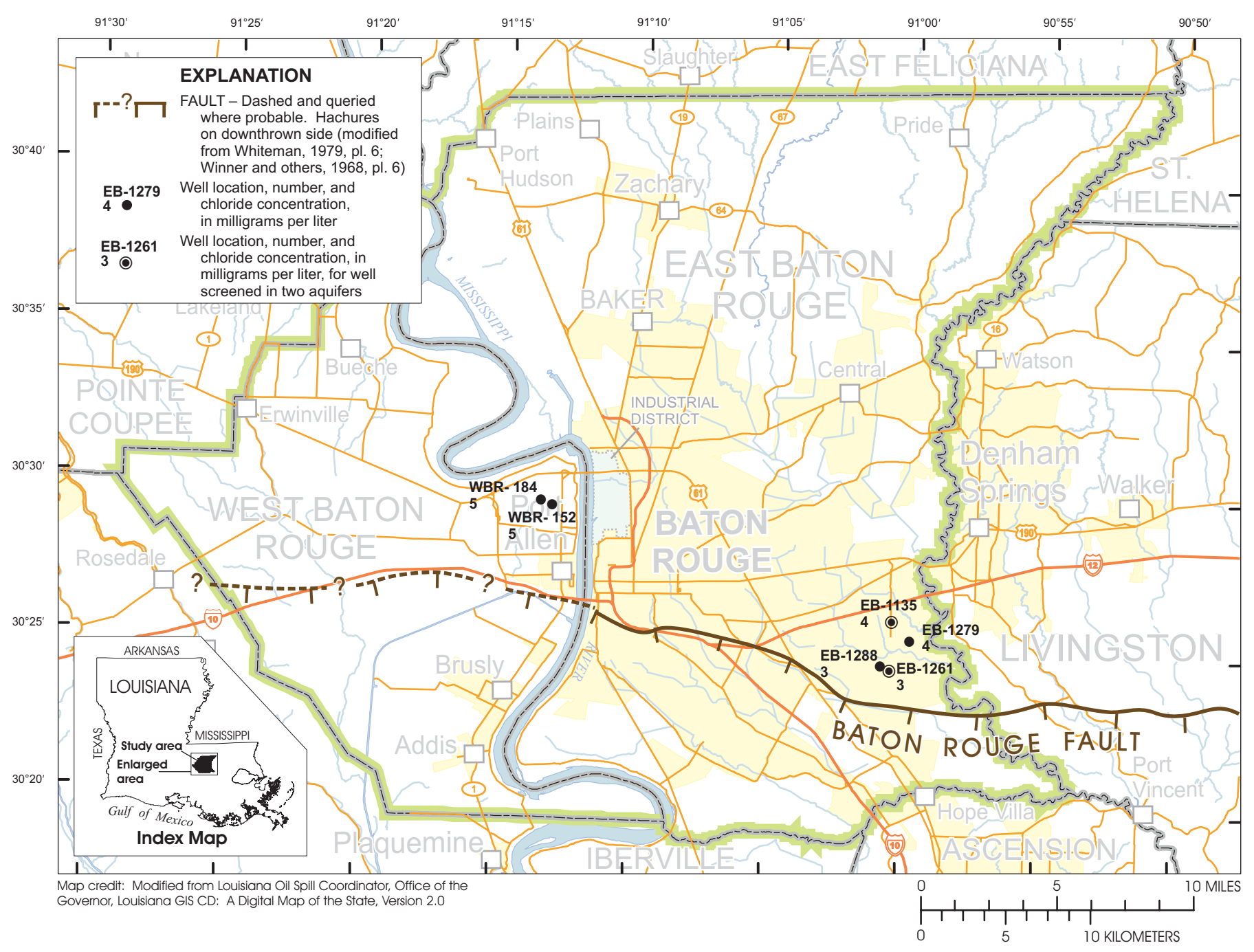

Figure 6. Chloride concentrations in water from wells screened in the "800-foot" sand of the Baton Rouge area in East and West Baton Rouge Parishes, Louisiana, 2004-05.

\section{“600-Foot" Sand}

Samples were collected from 15 wells located north of the Baton Rouge fault. Chloride concentrations exceeded background concentrations at two wells, EB-434 (49.4 mg/L) and EB-793 (29.2 mg/L), located between the fault and the industrial district, and at well EB-1171, located north of the industrial district (fig. 4). Increasing chloride concentrations at well EB-793 (fig. 5), located at the leading edge of the saltwater defined by Whiteman (1979), could indicate northward advancement of saltwater toward the Baton Rouge industrial district.

\section{“800-Foot" Sand}

Samples were collected from two wells located near Port Allen, La., in West Baton Rouge Parish and four wells in southeastern East Baton Rouge Parish. Chloride concentrations did not exceed background concentrations at any sampled wells (fig. 6, table 2). No increase in chloride concentrations was indicated.

\section{“1,000-Foot" Sand}

Chloride concentrations at 13 of 15 sampled wells did not exceed background concentrations (fig. 7, table 2). The chloride concentration at well EB-805, located just north of the Baton Rouge fault, was $9,140 \mathrm{mg} / \mathrm{L}$, the highest chloride concentration determined during the study. Chloride concentrations at well EB-805 have increased continuously since 1965, indicating saltwater leakage across the fault (fig. 8). Chloride concentrations at well EB-1328, located about $2.5 \mathrm{mi}$ east of well EB-805, were as high as $222 \mathrm{mg} / \mathrm{L}$ (table 2). 


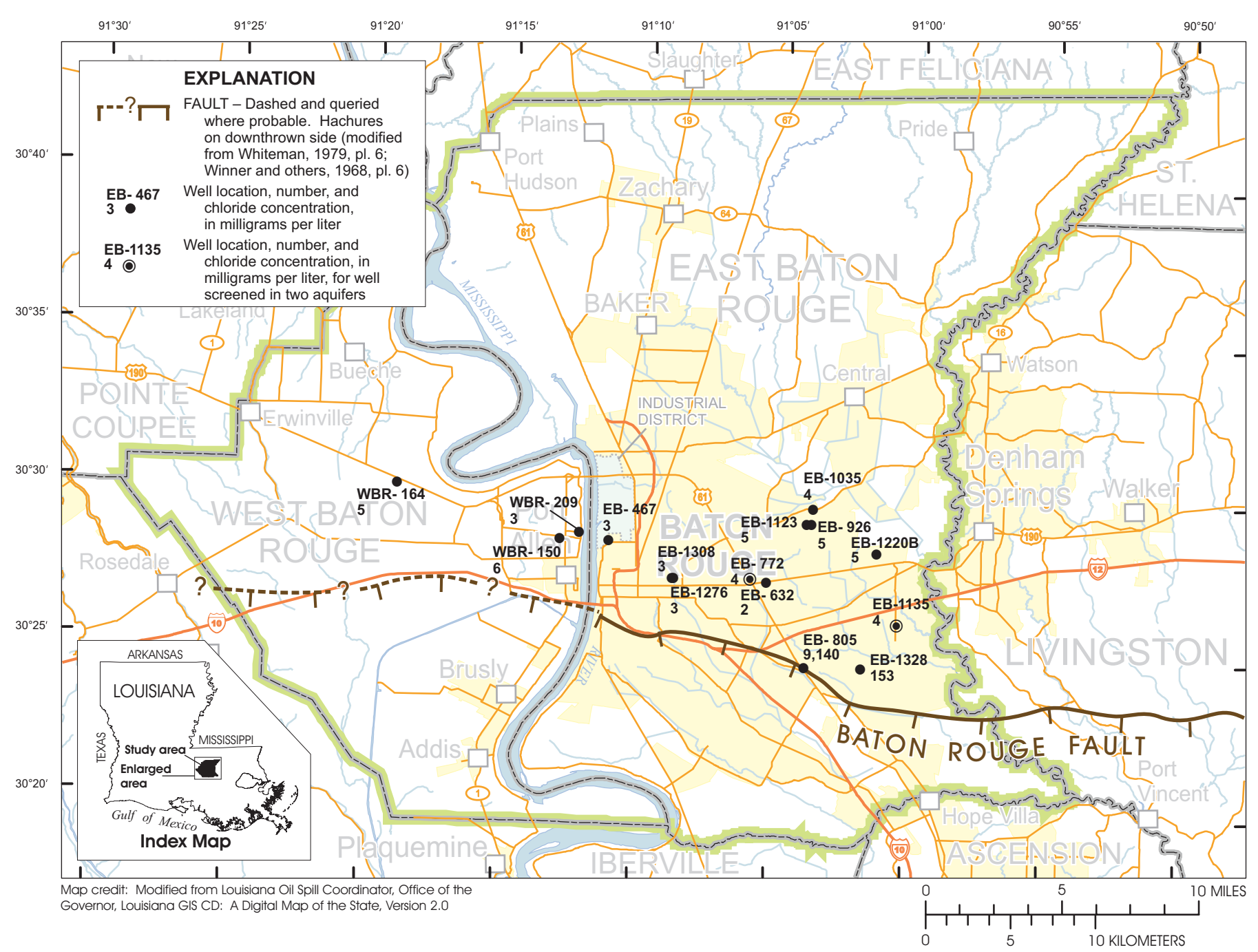

Figure 7. Chloride concentrations in water from wells screened in the "1,000-foot" sand of the Baton Rouge area in East and West Baton Rouge Parishes, Louisiana, 2004-05.

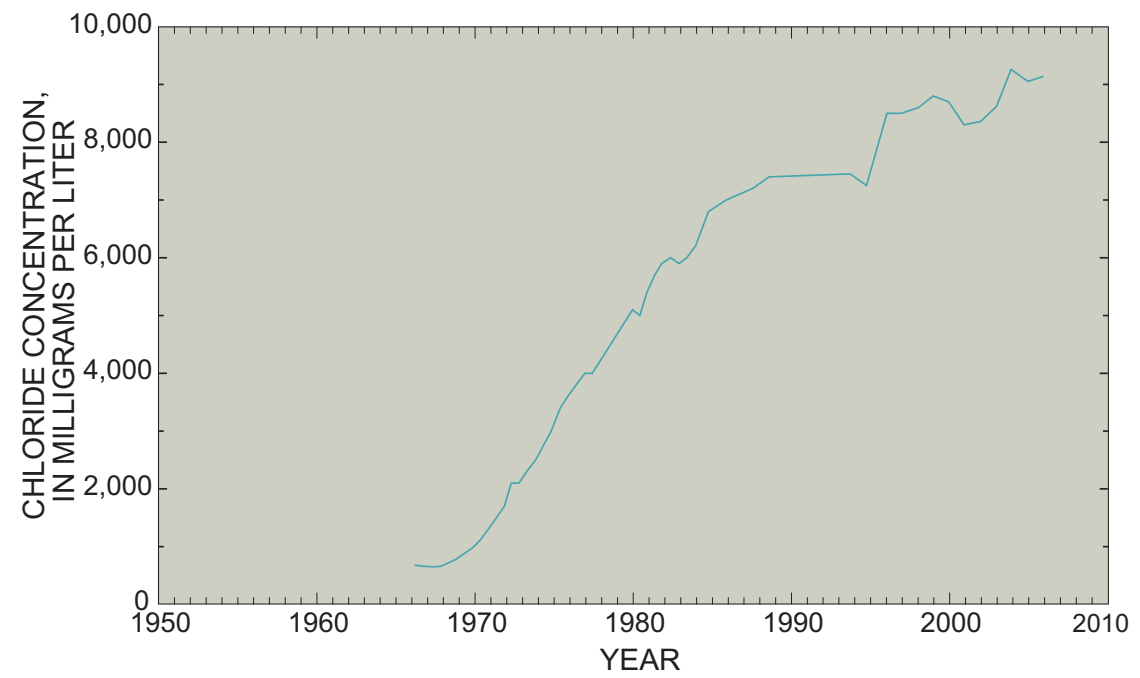

Figure 8. Chloride concentrations in water from well EB-805 screened in the "1,000-foot" sand of the Baton Rouge area, Louisiana (see fig. 7 for well location).

\section{“1,200-Foot" Sand}

Chloride concentrations at 24 of 26 sampled wells did not exceed background concentrations (fig. 9, table 2). Chloride concentration at well EB-629, located north of the industrial district, was $12.1 \mathrm{mg} / \mathrm{L}$. Chloride concentrations at well EB-621, located just north of the Baton Rouge fault, have exceeded background concentrations since the late 1970's, but had not exceeded 60 mg/L until 2004. Chloride concentrations at the well increased to more than $150 \mathrm{mg} / \mathrm{L}$ in 2005 (fig. 10). The increase in chloride concentrations at well EB-621 indicates continued saltwater leakage across the fault in the "1,200-foot" sand. 


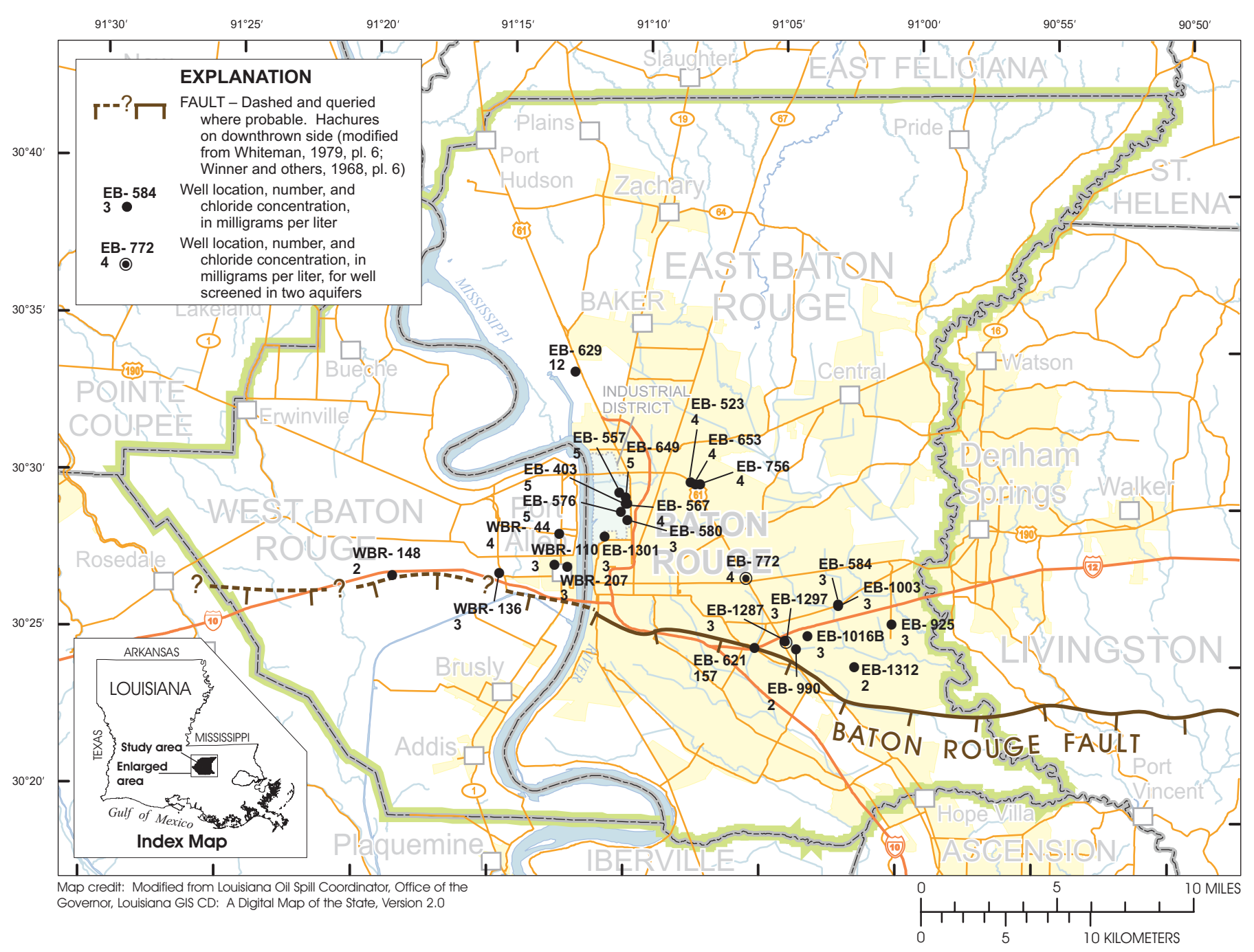

Figure 9. Chloride concentrations in water from wells screened in the "1,200-foot" sand of the Baton Rouge area in East and West Baton Rouge Parishes, Louisiana, 2004-05.

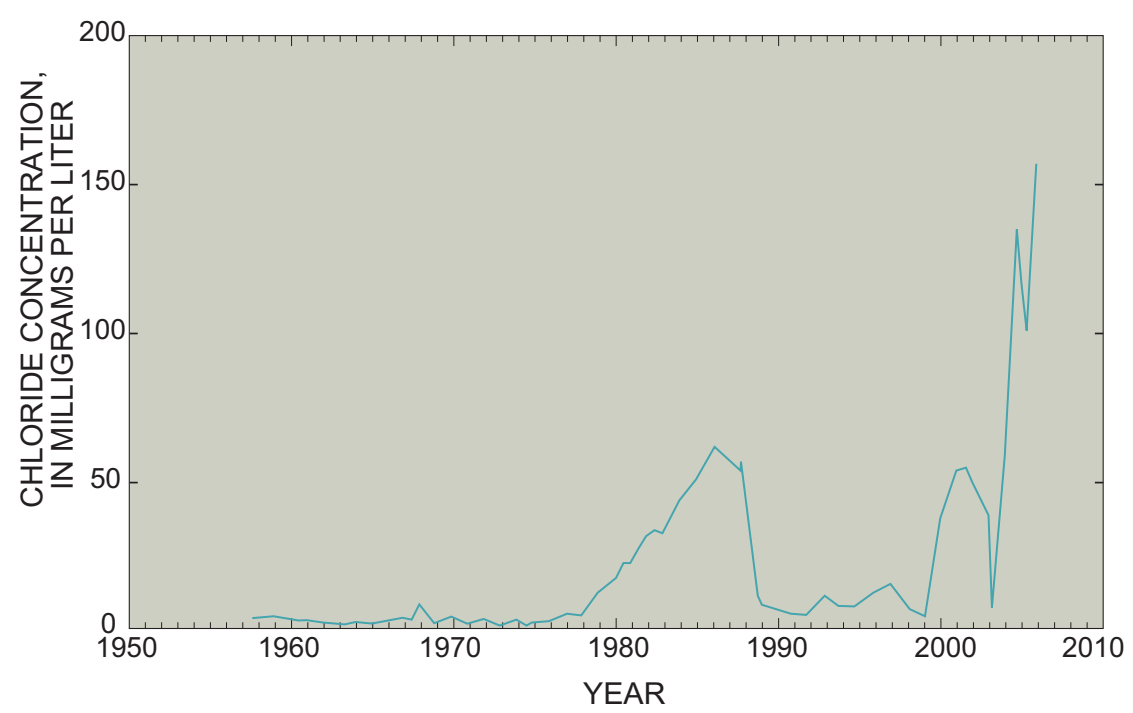

Figure 10. Chloride concentrations in water from well EB-621 screened in the "1,200-foot" sand of the Baton Rouge area, Louisiana (see fig. 9 for well location).

\section{“1,500-Foot" Sand}

Chloride concentrations at 11 of 21 sampled wells exceeded background concentrations (fig. 11, table 2). In East Baton Rouge Parish, chloride concentrations exceeded background concentrations at wells EB-413, EB-510, EB-658, EB-917, EB-918, EB-938, and EB-1295C. Chloride concentrations at wells EB-917 and EB-918, located just north of the Baton Rouge fault, have continued to increase and currently (2004-05) are at 64.8 and $1,010 \mathrm{mg} / \mathrm{L}$ (fig. 12). Chloride concentrations also have increased at wells EB-413 (14.8 mg/L), EB-771 (9.14 mg/L), EB-510 (11.2 mg/L), and EB-658 (55.8 mg/L), indicating that saltwater is moving northward (figs. 13 and 14). Well EB-1295C is 


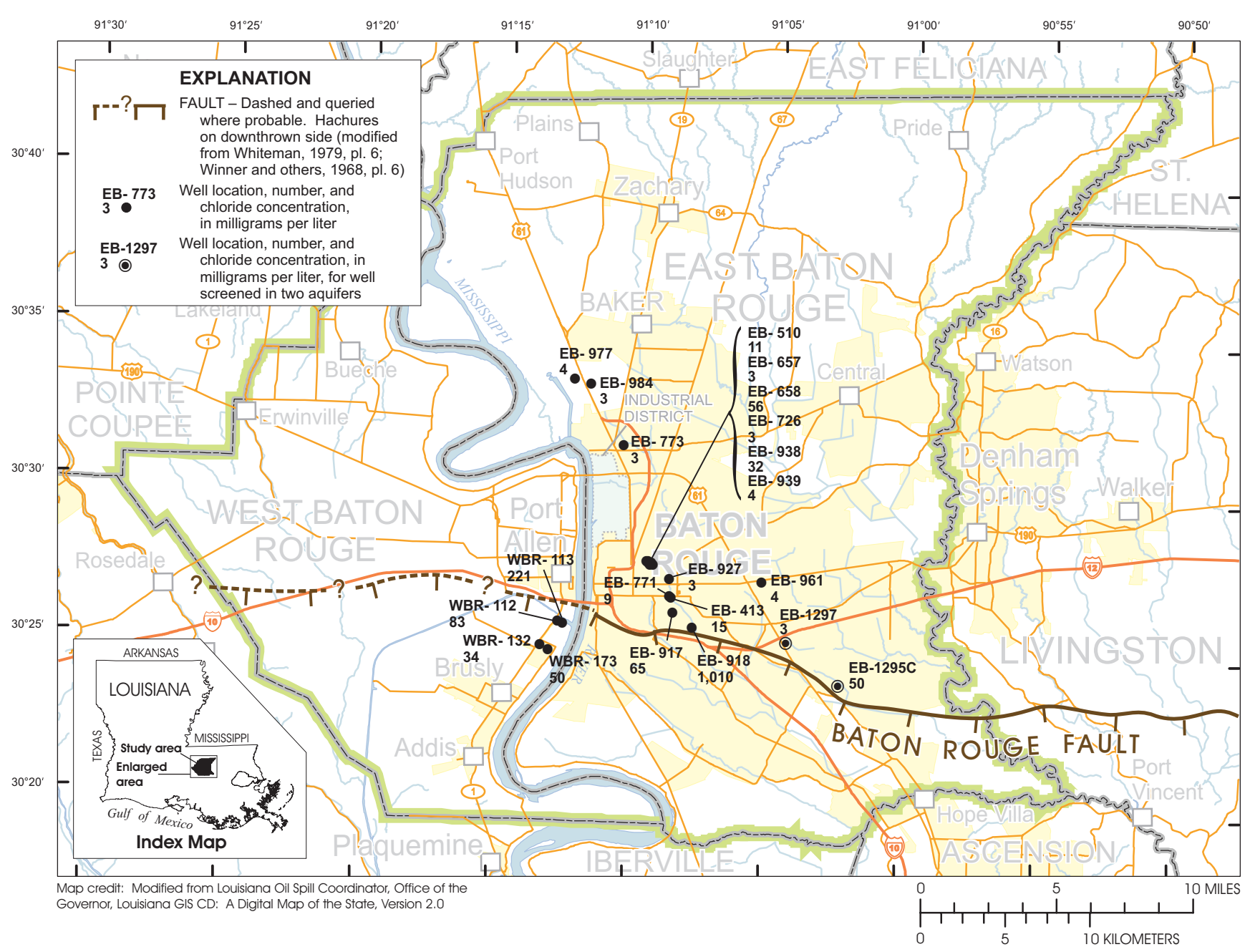

Figure 11. Chloride concentrations in water from wells screened in the "1,500-foot" sand of the Baton Rouge area in East and West Baton Rouge Parishes, Louisiana, 2004-05.

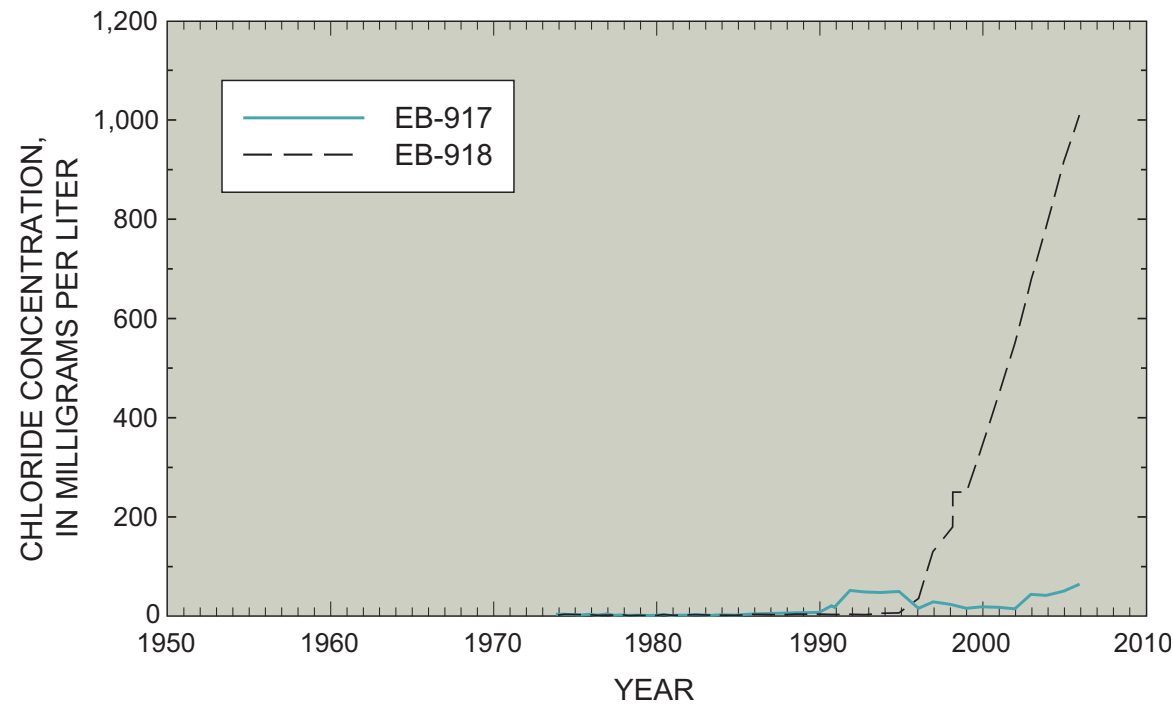

Figure 12. Chloride concentrations in water from wells EB-917 and EB-918 screened in the "1,500-foot" sand of the Baton Rouge area, Louisiana (see fig. 11 for well locations). screened in both the "1,500-foot" sand and the deeper "1,700-foot" sand, and it is not known which aquifer is the source of the saltwater at the well.

Tomaszewski (1998) documented an area in West Baton Rouge Parish where the "1,500-foot" sand locally contains freshwater south of the fault. Chloride concentrations have increased at all four wells sampled in the area (figs. 15 and 16). Saltwater may be encroaching toward the wells from the surrounding saltwater areas (Tomaszewski, 1998, p. 13).

\section{“1,700-Foot" Sand}

Chloride concentrations at seven of eight sampled wells did not exceed background concentrations (fig. 17, 

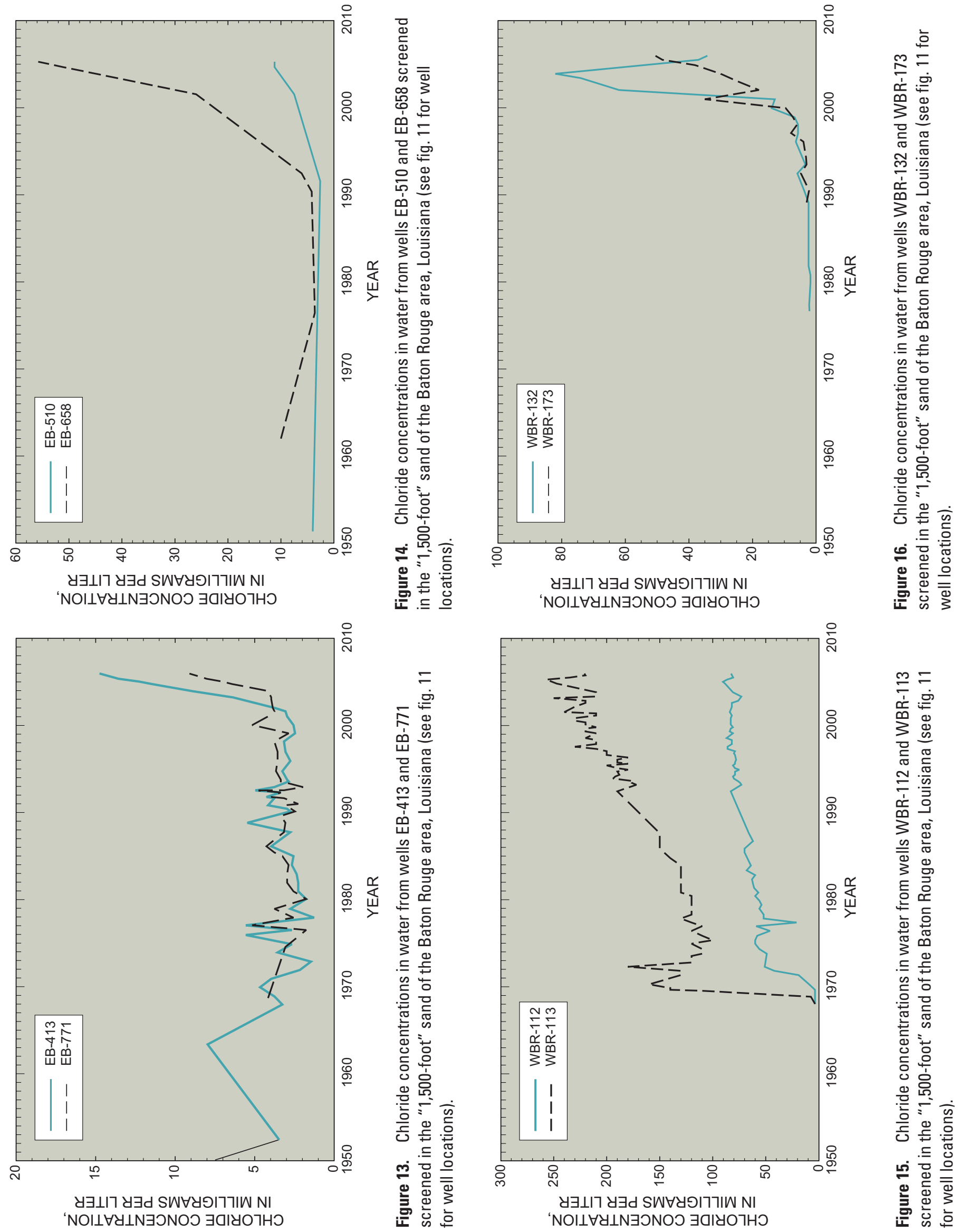
table 2). The chloride concentration was $50.3 \mathrm{mg} / \mathrm{L}$ at well EB-1295C, which is screened in both the "1,500-foot" and "1,700-foot" sands. It is not known which aquifer is the source of the saltwater at the well, and historical data for the well are insufficient to determine whether chloride concentrations at the well are changing over time.

\section{"2,000-Foot" Sand}

Samples were collected from 25 wells located north of the Baton Rouge fault and 3 wells located south of the fault (fig. 18, table 2). North of the fault, chloride concentrations exceeded background concentrations at three wells, EB-630, EB-1028, and EB-1150, located between the fault and the industrial district. Chloride concentrations at the wells exceeded $100 \mathrm{mg} / \mathrm{L}$ and have increased (fig. 19). Movement of saltwater in the "2,000-foot" sand toward withdrawal centers in the industrial district was documented by Tomaszewski (1996). The chloride concentration at well EB-783B, located
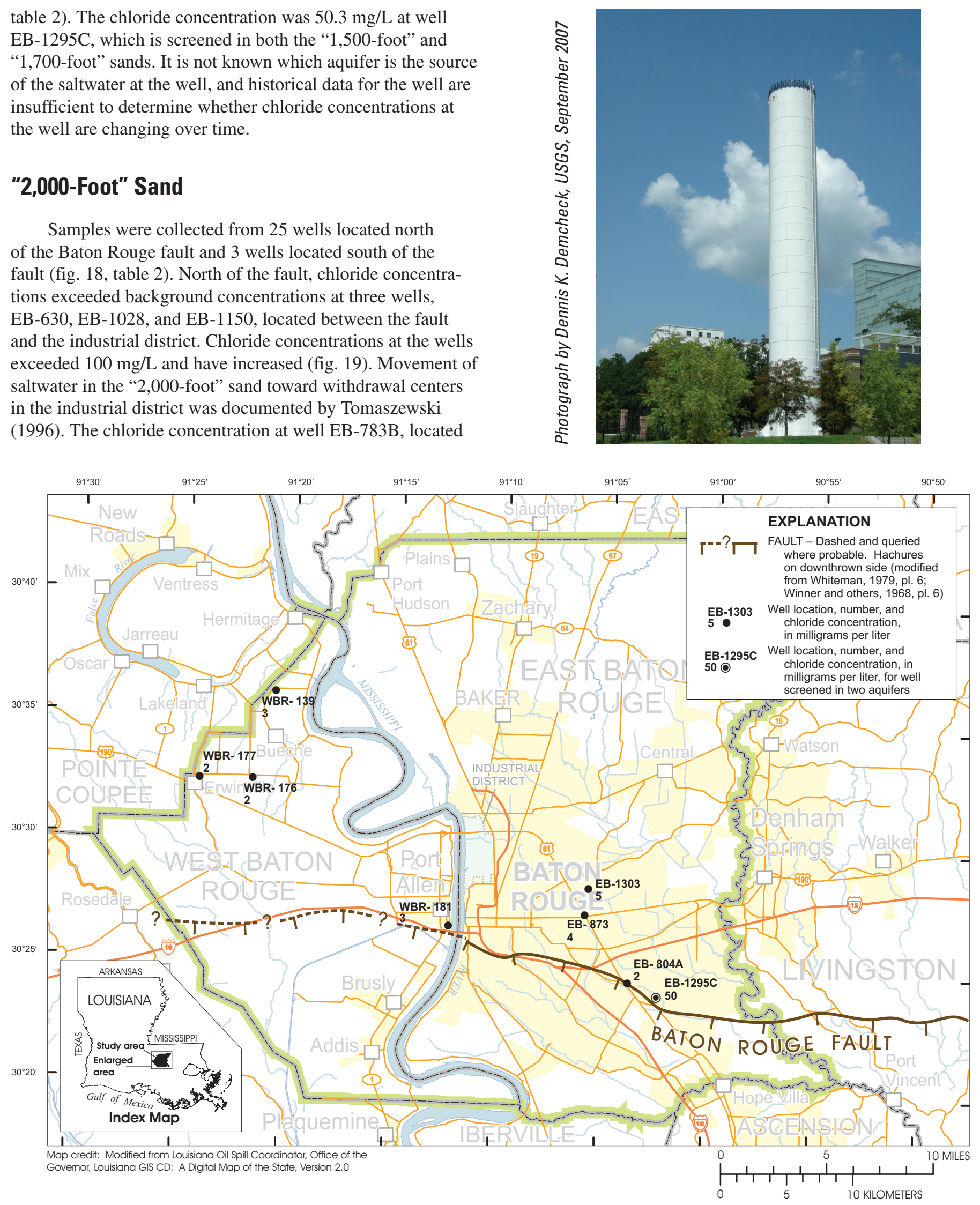

Figure 17. Chloride concentrations in water from wells screened in the "1,700-foot" sand of the Baton Rouge area in East and West Baton Rouge Parishes, Louisiana, 2004-05. 


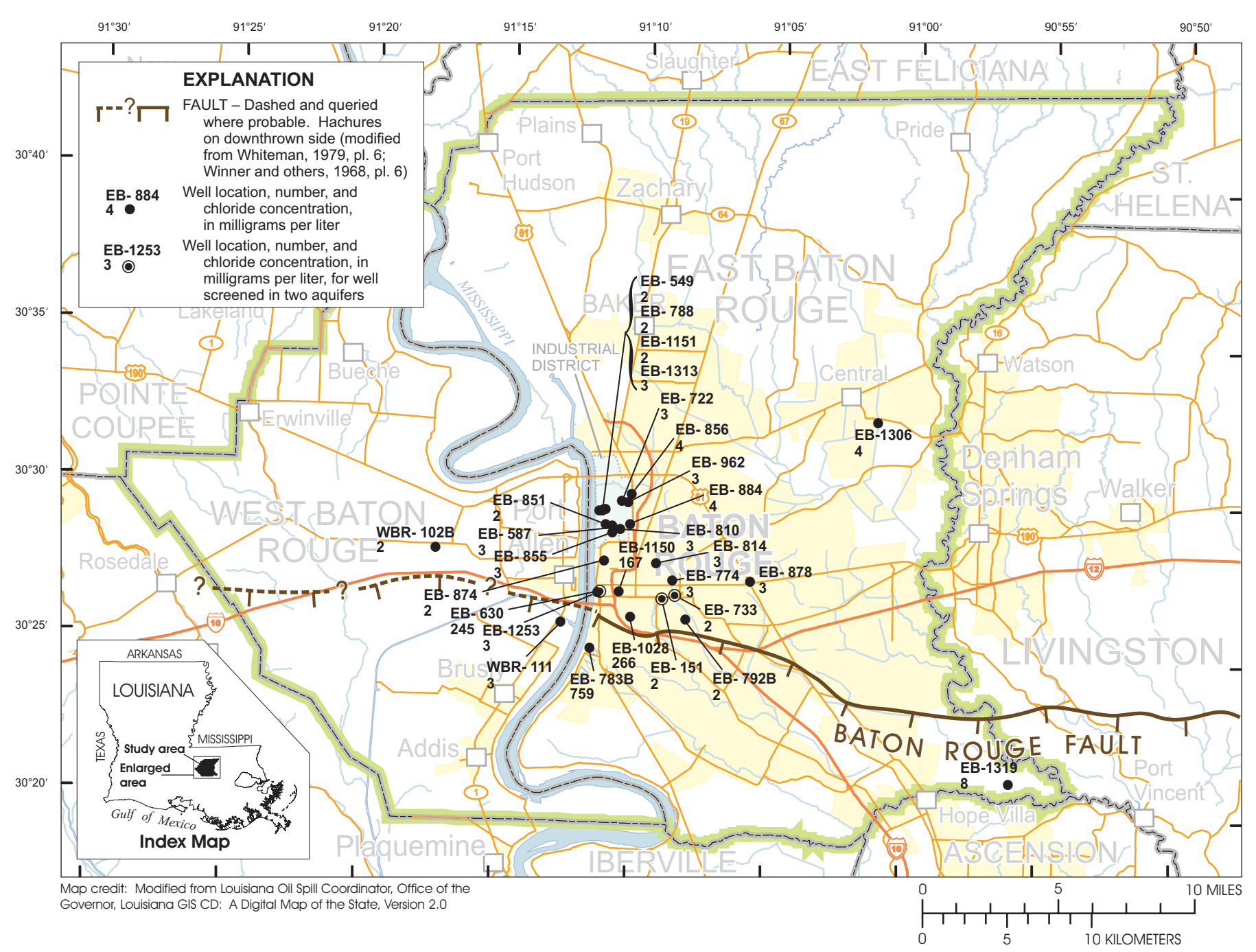

Figure 18. Chloride concentrations in water from wells screened in the "2,000-foot" sand of the Baton Rouge area in East and West Baton Rouge Parishes, Louisiana, 2004-05.

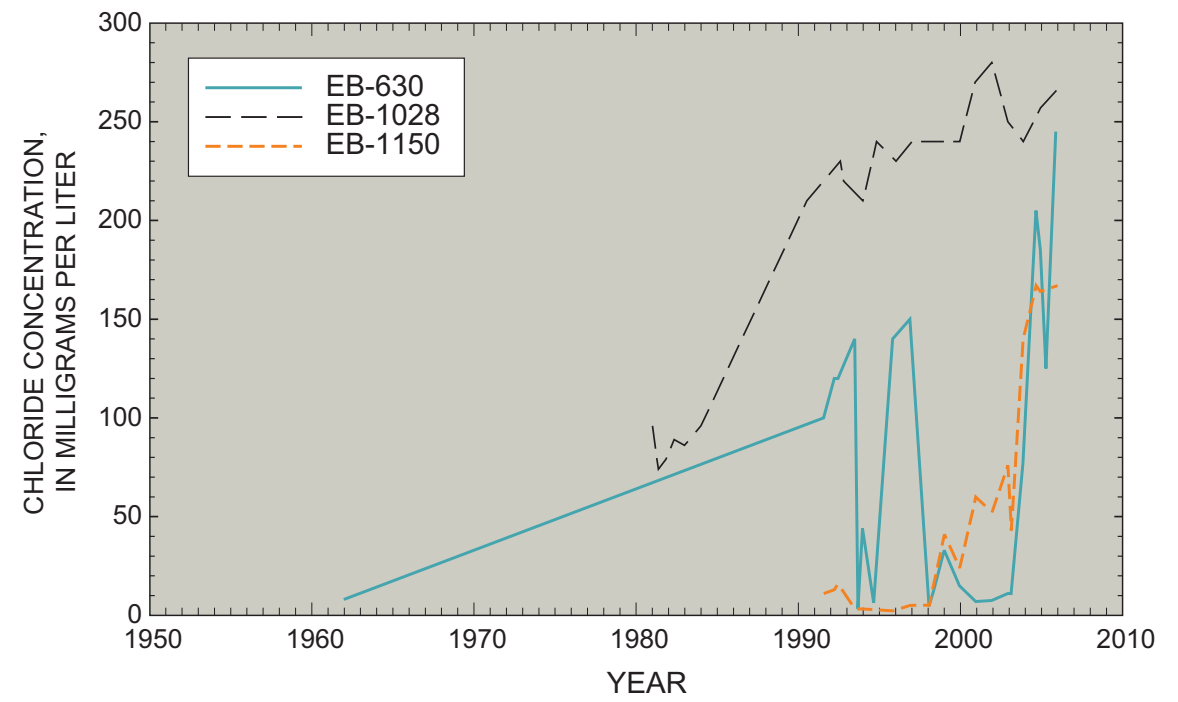

Figure 19. Chloride concentrations in water from wells EB-630, EB-1028, and EB-1150 screened in the "2,000-foot" sand of the Baton Rouge area, Louisiana (see fig. 18 for well locations). about 2 mi south of well EB-630 and south of the Baton Rouge fault, was $759 \mathrm{mg} / \mathrm{L}$.

\section{"2,400-Foot" Sand}

Chloride concentrations at 20 of 21 sampled wells did not exceed background concentrations (fig. 20, table 2). Chloride concentrations at well EB-804B, located just north of the Baton Rouge fault in south-central East Baton Rouge Parish, exceeded $100 \mathrm{mg} / \mathrm{L}$ and have increased since about 1993, indicating that saltwater is moving across the fault in that area (fig. 21). 


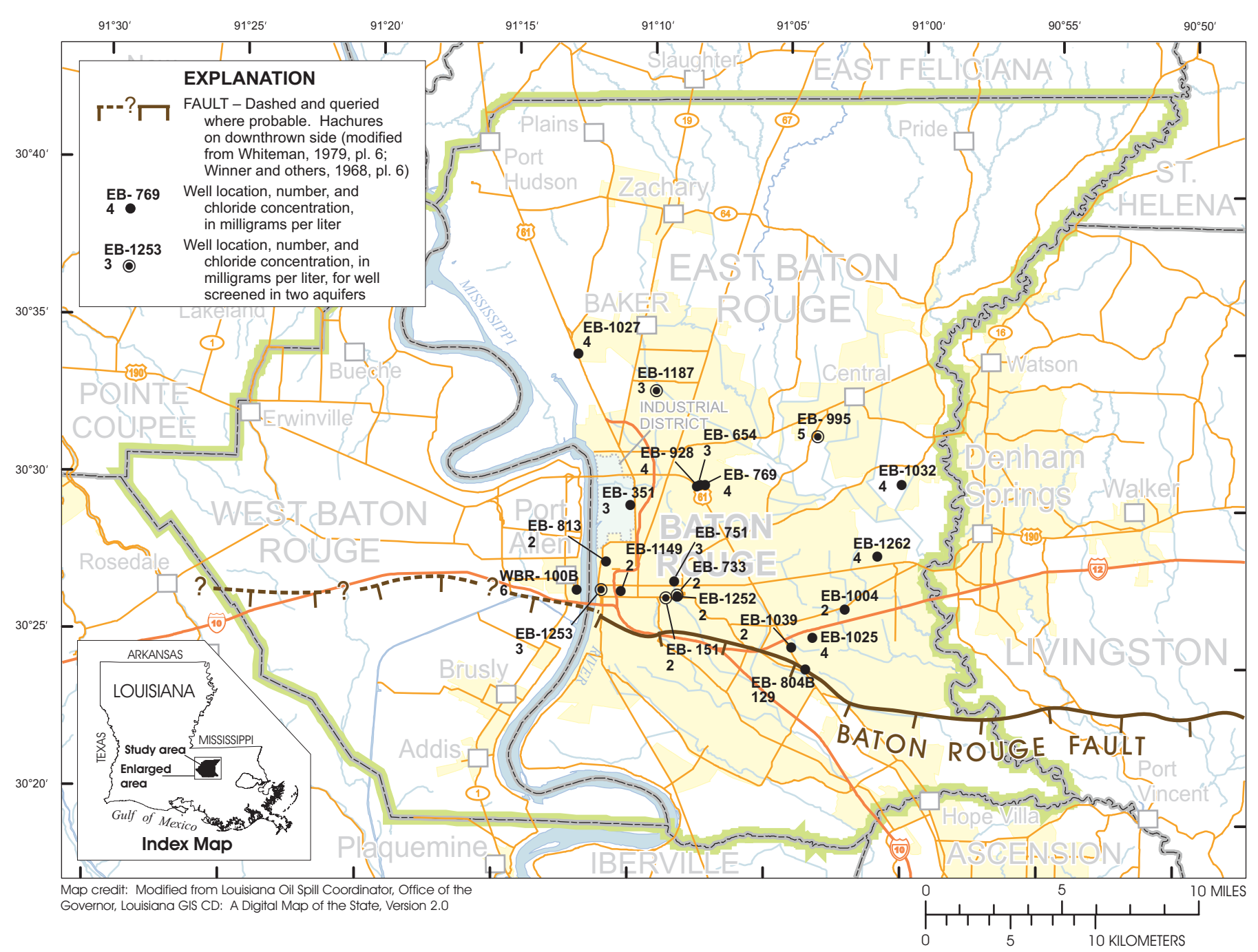

Figure 20. Chloride concentrations in water from wells screened in the "2,400-foot" sand of the Baton Rouge area in East and West Baton Rouge Parishes, Louisiana, 2004-05.

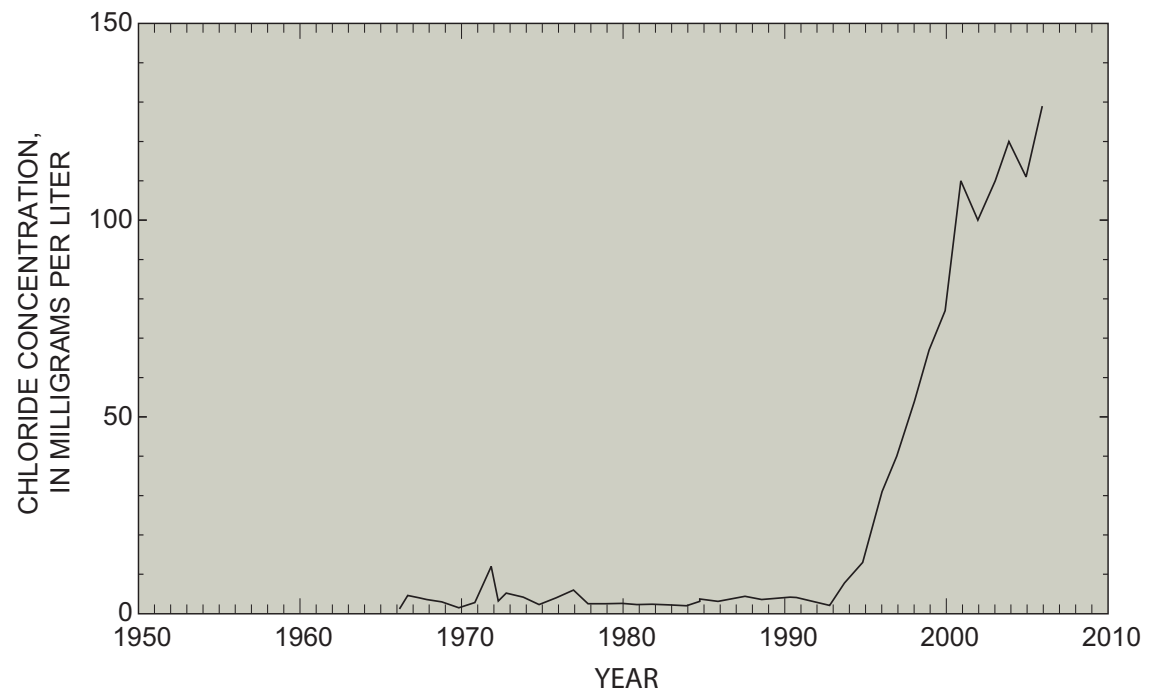

Figure 21. Chloride concentrations in water from well EB-804B screened in the "2,400-foot" sand of the Baton Rouge area, Louisiana (see fig. 20 for well location).

\section{"2,800-Foot" Sand}

Wells screened in the " 2,800 foot" sand generally are located in the northern half of East Baton Rouge Parish because the " 2,800 foot" sand contains saltwater from the Baton Rouge fault to about $2 \mathrm{mi}$ north of the fault. A zone of transition from saltwater to freshwater farther extends from about 2 to $7 \mathrm{mi}$ north of the fault and ends just north of the Baton Rouge industrial district (Tomaszewski, 1996, p. 27). Chloride concentrations at 11 of 16 sampled wells located north of the transition zone did not exceed background 


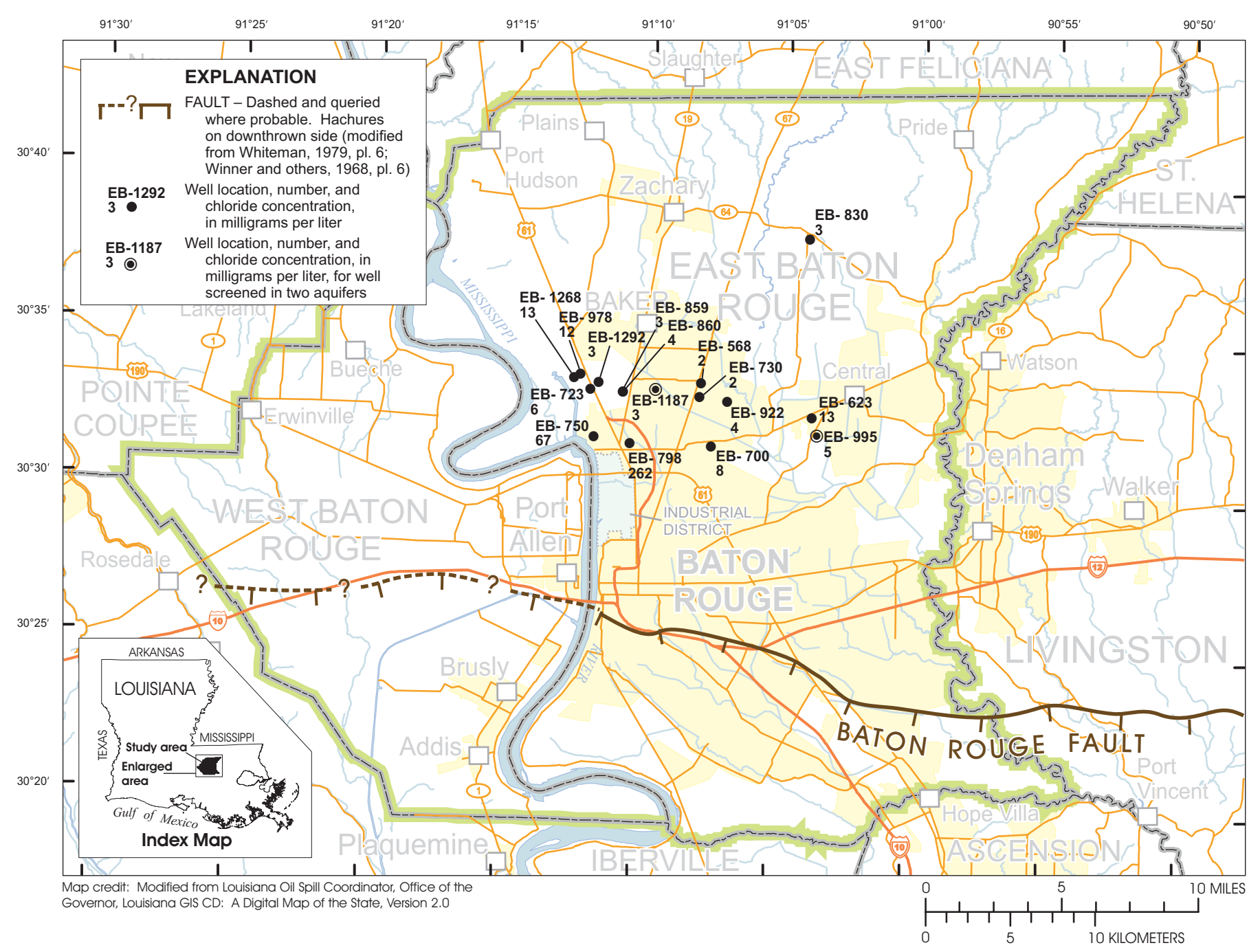

Figure 22. Chloride concentrations in water from wells screened in the "2,800-foot" sand of the Baton Rouge area in East and West Baton Rouge Parishes, Louisiana, 2004-05.

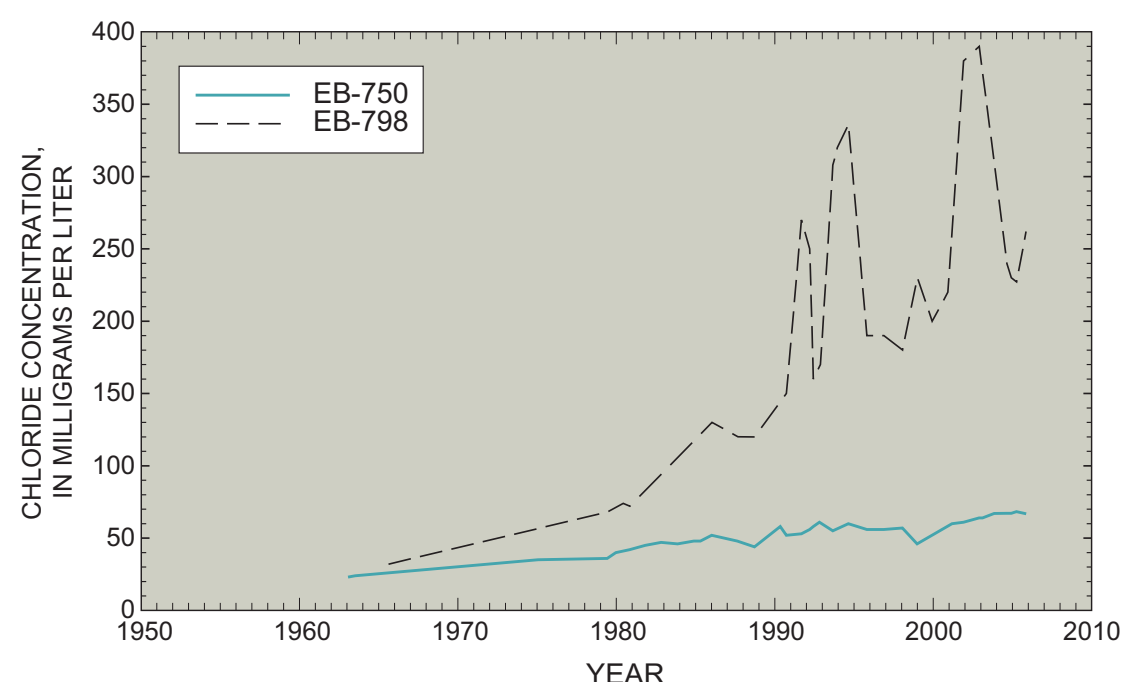

Figure 23. Chloride concentrations in water from wells EB-750 and EB-798 screened in the "2,800-foot" sand of the Baton Rouge area, Louisiana (see fig. 22 for well locations). concentrations (fig. 22, table 2). Chloride concentrations at wells EB-623, EB-978, and EB-1268 ranged from 11.5 to $12.9 \mathrm{mg} / \mathrm{L}$. Chloride concentrations at two of the southernmost wells, EB-750 and EB-798, were greater than background concentrations (67.2 and $262 \mathrm{mg} / \mathrm{L}$ ) and increasing (fig. 23). Because these wells are located within the freshwater-saltwater transition zone (Tomaszewski, 1996, p. 29), the increasing chloride concentrations could be due to upconing of saltwater from the base and do not necessarily indicate that saltwater in the " 2,800 foot" sand is moving northward in the area. 


\section{Summary}

Increasing chloride concentrations are a threat to fresh ground-water sources in East and West Baton Rouge Parishes, Louisiana. Large withdrawals at Baton Rouge have lowered water levels and altered flow patterns in most of the 10 aquifers that underlie the area. Prior to development, freshwater flowed southward to the Baton Rouge fault, an east-west trending growth fault that extends through Baton Rouge and across southeastern Louisiana. Aquifers south of the fault generally contain saltwater. Ground-water withdrawals north of the fault have created gradients favorable for the movement of saltwater from south of the fault into freshwater areas north of the fault.

By 1992, saltwater encroachment had been documented in the "600-foot," "800-foot," "1,000-foot," "1,500-foot," and "2,000-foot" sands underlying East and West Baton Rouge Parishes. The presence of saltwater, but not encroachment, also had been documented in the "400-foot, "1,200-foot," and "2,800-foot" sands north of the Baton Rouge fault. Data collected from 1993 to 2003 from wells on a chloridemonitoring network indicate concentrations of chloride have increased in wells in the "1,000-foot," "1,500-foot," "2,000foot," "2,400-foot," and "2,800-foot" sands in East and West Baton Rouge Parishes.

Water samples were collected from 152 wells during 2004-05 to document chloride concentrations in aquifers underlying East and West Baton Rouge Parishes. Chloride concentrations exceeded $10 \mathrm{mg} / \mathrm{L}$ (milligrams per liter) in samples from 23 wells located north of the Baton Rouge fault and indicated the possible presence of saltwater in 8 of the 10 aquifers. Comparison of the sample results with historical data indicated that chloride concentrations are increasing at wells north of the Baton Rouge fault in seven of the aquifers.

Chloride concentrations at wells screened in the "400-foot" sand north of the Baton Rouge fault did not exceed background concentrations and no increase in chloride concentrations was indicated at the wells. A large-diameter well, EB-1298, screened in the "400-foot" sand south of the fault in the southeast corner of East Baton Rouge Parish, was sampled and had a chloride concentration of $17.1 \mathrm{mg} / \mathrm{L}$. No increase in chloride concentrations was indicated at well EB-1298.

Chloride concentrations exceeded background concentrations at two wells, EB-434 (49.4 mg/L) and EB-793 $(29.2 \mathrm{mg} / \mathrm{L})$, screened in the "600-foot" sand and located between the fault and the industrial district, and at one well located north of the industrial district. Increasing chloride concentrations at well EB-793 could indicate northward advancement of saltwater toward the Baton Rouge industrial district.

The chloride concentration at well EB-805, screened in the "1,000-foot" sand and located just north of the Baton Rouge fault, was $9,140 \mathrm{mg} / \mathrm{L}$, the highest chloride concentration determined during the study. Chloride concentrations at well EB-805 have increased continuously since 1965, indicating saltwater leakage across the fault. Chloride concentrations at well EB-1328, located about 2.5 miles east of well EB-805, were as high as $222 \mathrm{mg} / \mathrm{L}$.

Chloride concentrations at well EB-621, located just north of the Baton Rouge fault, have exceeded background concentrations since the late 1970's, but had not exceeded $60 \mathrm{mg} / \mathrm{L}$ until 2004. Chloride concentrations at the well increased to more than $150 \mathrm{mg} / \mathrm{L}$ in 2005 . The increase in chloride concentrations at well EB-621 indicates continued saltwater leakage across the fault in the "1,200-foot" sand.

Chloride concentrations at 11 of 21 sampled wells screened in the "1,500-foot" sand exceeded background concentrations. Chloride concentrations at wells EB-917 and EB-918, located just north of the Baton Rouge fault, have continued to increase and currently (2004-05) are at 65 and $1,010 \mathrm{mg} / \mathrm{L}$. Chloride concentrations also have increased at wells EB-413 (14.8 mg/L), EB-771 (9.14 mg/L), EB-510 (11.2 mg/L), and EB-658 (55.8 mg/L), indicating that saltwater is moving northward in the "1,500-foot" sand. Chloride concentrations also increased in four wells sampled south of the fault in West Baton Rouge Parish in the area where the "1,500-foot" sand locally contains freshwater south of the fault.

Chloride concentrations in the "2,000-foot" sand exceeded background concentrations at three wells, EB-630, EB-1028, and EB-1150, located between the fault and the industrial district. Chloride concentrations at the wells exceeded $100 \mathrm{mg} / \mathrm{L}$ and have increased. Saltwater in the "2,000-foot" sand is moving toward withdrawal centers in the industrial district.

Chloride concentrations at well EB-804B, screened in the "2,400-foot" sand and located just north of the Baton Rouge fault in south-central East Baton Rouge Parish, exceeded 100 $\mathrm{mg} / \mathrm{L}$. Chloride concentrations at the well have increased since about 1993, indicating that saltwater is moving across the fault in that area.

Wells screened in the "2,800-foot" sand generally are located in the northern half of East Baton Rouge Parish because the "2,800-foot" sand contains saltwater from the Baton Rouge fault to about 2 miles north of the fault. A zone of transition from saltwater to freshwater farther extends from about 2 to 7 miles north of the fault and ends just north of the Baton Rouge industrial district. Chloride concentrations at two of the southernmost wells, EB-750 and EB-798, were greater than background concentrations (67.2 and $262 \mathrm{mg} / \mathrm{L}$ ) and increasing. Because these wells are located within the freshwater-saltwater transition zone, the increasing chloride concentrations could be due to upconing of saltwater from the base and do not necessarily indicate that saltwater in the "2,800-foot" sand is moving northward in the area. 


\section{Selected References}

Buono, Anthony, 1983, The Southern Hills regional aquifer system of southeastern Louisiana and southwestern Mississippi: U.S. Geological Survey Water-Resources Investigations Report 83-4189, 38 p.

Durham, C.O., Jr., and Peeples, E.M. III, 1956, Pleistocene fault zone in southeastern Louisiana [abs.]: Transactions of the Gulf Coast Association of Geological Societies, v. 6, p. 65-66.

Fishman, M.J., and Friedman, L.C., eds., 1989, Methods for determination of inorganic substances in water and fluvial sediments: U.S. Geological Survey Techniques of Water-Resources Investigations, book 5, chap. A1, 545 p. [Also available online at URL http://pubs.water.usgs. gov/twri/. Chapters originally published from 1997-99; updates and revisions are ongoing and are summarized at URL http://water.usgs.gov/owq/FieldManual/mastererrata. html]

Lovelace, J.K., and Lovelace, W.M., 1995, Hydrogeologic unit nomenclature and computer codes for aquifers and confining units in Louisiana: Louisiana Department of Transportation and Development Water Resources Special Report no. $9,12 \mathrm{p}$.

Meyer, R.R., and Turcan, A.N., Jr., 1955, Geology and ground-water resources of the Baton Rouge area, Louisiana: U.S. Geological Survey Water-Supply Paper 1296, 138 p.

Morgan, C.O., 1961, Ground-water conditions in the Baton Rouge area, 1954-59, with special reference to increased pumpage: Department of Conservation, Louisiana Geological Survey, and Louisiana Department of Public Works Water Resources Bulletin no. 2, 78 p.

Morgan, C.O., 1963, Ground-water resources of East Feliciana and West Feliciana Parishes, Louisiana: Louisiana Department of Public Works, 58 p.

Morgan, C.O., and Winner, M.D., Jr., 1964, Salt-water encroachment in aquifers of the Baton Rouge areapreliminary report and proposal: Louisiana Department of Public Works, 37 p.

National Oceanic and Atmospheric Administration, 1995, Climatological data annual summary-Louisiana: Asheville, N.C., Environmental Data Service, 23 p.

Stuart, C.G., Knochenmus, Darwin, and McGee, B.D., 1994, Guide to Louisiana's ground-water resources: U.S. Geological Survey Water-Resources Investigations Report 94-4085, $55 \mathrm{p}$.
Rollo, J.R., 1969, Saltwater encroachment in aquifers of the Baton Rouge area, Louisiana: Department of Conservation, Louisiana Geological Survey, and Louisiana Department of Public Works Water Resources Bulletin no. 13, 45 p.

Tomaszewski, D.J., 1996, Distribution and movement of saltwater in aquifers in the Baton Rouge area, Louisiana, 1990-92: Louisiana Department of Transportation and Development Water Resources Technical Report no. 59, $44 \mathrm{p}$.

Tomaszewski, D.J., 1998, Hydrogeology and the effects of pumpage on the "1,500-foot" sand south of the Baton Rouge fault, near Brusly, Louisiana, 1996: Louisiana Department of Transportation and Development Water Resources Technical Report no. 65, 22 p.

Tomaszewski, D.J., and Anderson, M.L., 1995, Data from wells in a chloride monitoring network, Baton Rouge area, Louisiana, 1965-94: Louisiana Department of Transportation and Development Water Resources Basic Records Report no. 19, 40 p.

U.S. Census Bureau, 2005, State and county quickfacts: accessed December 12, 2005, at URL http://quickfacts.census.gov/qfd/states/22000.html

U.S. Environmental Protection Agency, 2006, Drinking water contaminants: accessed December 28, 2006, at URL http://www.epa.gov/safewater/contaminants/index.html

U.S. Geological Survey, (1997-present), National field manual for the collection of water-quality data: U.S. Geological Survey Techniques of Water-Resources Investigations, book 9, chaps. A1-A9, 2 v., variously paged. [Also available online at URL http://pubs.water.usgs.gov/twri/. Chapters originally published from 1997-99; updates and revisions are ongoing and are summarized at URL http://water.usgs. gov/owq/FieldManual/mastererrata.html]

Whiteman, C.D., Jr., 1979, Saltwater encroachment in the "600-foot" and "1,500-foot" sands of the Baton Rouge area, Louisiana, 1966-78, including a discussion of saltwater in other sands: Louisiana Department of Transportation and Development, Office of Public Works Water Resources Technical Report no. 19, 49 p.

Winner, M.D., Jr., Forbes, M.J., Jr., and Broussard, W.L., 1968, Water resources of Pointe Coupee Parish, Louisiana: Department of Conservation, Louisiana Geological Survey, and Louisiana Department of Public Works Water Resources Bulletin no. 11, 110 p. 
Publishing support provided by: Lafayette Publishing Service Center 